NBER WORKING PAPER SERIES

\title{
EFFECTS OF THE FINANCIAL CRISIS AND GREAT RECESSION ON AMERICAN HOUSEHOLDS
}

\author{
Michael D. Hurd \\ Susann Rohwedder \\ Working Paper 16407 \\ http://www.nber.org/papers/w16407 \\ NATIONAL BUREAU OF ECONOMIC RESEARCH \\ 1050 Massachusetts Avenue \\ Cambridge, MA 02138 \\ September 2010
}

We are grateful to the National Institute on Aging for research support and funding for data collection under grants P01 AG008291, P01 AG022481, P30 AG012815, and R01 AG20717. We are grateful to the Social Security Administration for funding of data collection. Many thanks to the ALP team for their assistance with the data collection, to Joanna Carroll and Angela Miu for programming support, and to students from the Pardee RAND Graduate School, Claudia Diaz, Alessandro Malchiodi and Sarah Outcault, for able research assistance. The views expressed herein are those of the authors and do not necessarily reflect the views of the National Bureau of Economic Research.

NBER working papers are circulated for discussion and comment purposes. They have not been peerreviewed or been subject to the review by the NBER Board of Directors that accompanies official NBER publications.

(C) 2010 by Michael D. Hurd and Susann Rohwedder. All rights reserved. Short sections of text, not to exceed two paragraphs, may be quoted without explicit permission provided that full credit, including (C) notice, is given to the source. 
Effects of the Financial Crisis and Great Recession on American Households

Michael D. Hurd and Susann Rohwedder

NBER Working Paper No. 16407

September 2010

JEL No. D12,D31,D84,D91,J64

\begin{abstract}
$\underline{\text { ABSTRACT }}$
In this paper we present evidence from high-frequency data collections dedicated to tracking the effects of the financial crisis and great recession on American households. These data come from surveys that we conducted in the American Life Panel - an Internet survey run by RAND Labor and Population. The first survey was fielded at the beginning of November 2008, immediately following the large declines in the stock market of September and October 2008. The next survey followed three months later in February 2009. Since May 2009 we have collected monthly data on the same households. This paper shows the levels and trends of many of these data which summarize the experience and expectations of households during the recession.

We find that the effects of the recession are widespread: between November 2008 and April 2010 about 39 percent of households had either been unemployed, had negative equity in their house or had been in arrears in their house payments. Reductions in spending were common especially following unemployment. On average expectations about stock market prices and housing prices are pessimistic, particularly long-run expectations. Among workers, expectations about becoming unemployed have recovered somewhat from their low point in May 2009 but still remain high. Overall the data suggest that households are not optimistic about their economic futures.
\end{abstract}

Michael D. Hurd

RAND Corporation

1776 Main Street

Santa Monica, CA 90407

and NBER

mhurd@rand.org

Susann Rohwedder

RAND

1776 Main Street

P.O. Box 2138

Santa Monica, CA 90407

susannr@rand.org 


\section{Introduction}

According to the Case-Shiller 20-city average housing price index, housing prices reached a maximum in May 2006. Problems in the housing market associated with the subsequent decline in prices and with the relaxed lending standards during the run-up in prices spread to the financial sector leading to the financial crisis. At the beginning of the crisis unemployment was quite low: in December 2007 when the economy entered recession the rate was just 5\%. However, housing prices continued to decline and stock prices, which had been increasing as measured by the S\&P500, began to decline in October 2007. By October 31, 2008 the S\&P500 was down 37\% from a year earlier and it had dropped 17\% in the month of October 2008 alone. The Case-Shiller index was down $18 \%$ from a year earlier. The unemployment rate was $6.2 \%$ in September 2008 up from 4.7\% in September 2007 but the increase was modest relative to the problems associated with the financial crisis. However, the unemployment rate increased to 6.6\% in October, to 6.9\% in November and to 7.4\% in December 2008. The financial crisis had become the Great Recession.

The effects of this recession are likely different from prior recessions because of simultaneous shocks in the stock market, the housing market and the labor market. For example in the recession of 1981-1982 the unemployment rate increased from $7.2 \%$ to $10.8 \%$ but housing prices were approximately constant and the stock market rose. In the short recession of 2001 associated with the stock market crash, the unemployment rate increased from $4.3 \%$ to $5.5 \%$, but housing prices increased by about $4 \%$. Besides the simultaneity of the shocks, circumstances have changed. The transition from a DB pension world to a DC pension world meant that the retirement assets of more older workers were affected by a stock market decline. Balloon loans and small or no down payments for houses meant that many faced increasing mortgage payments even as they had negative equity. Younger or lower paid workers were admitted into the housing market during the boom years, but that same group was more likely to be subsequently unemployed: not being able to make their house payments, many were foreclosed. The sharp decline in the stock market reduced the buffer that might have ameliorated distress from the housing or labor market.

In this paper we present results about the effects of the economic crisis and recession on American households. They come from high-frequency surveys dedicated to tracking the effects of the crisis and recession that we conducted in the American Life Panel - an Internet survey run by RAND Labor and Population. The first survey was fielded at the beginning of November 2008, immediately following the large declines in the stock market of September and October. The next survey followed three months later in February 2009. Since May 2009 we have collected monthly data on the same households.

Our main measures are actual spending, unemployment, home equity, affect and mood, and expectations about the stock market, the housing market and unemployment. While there is some variation in the time path of these measures, mostly they declined from the beginning of our surveys and continued to decline beyond June 2009, the official end of the recession, reaching their low points in June-November 2009. Since then, they have shown little improvement. If we define recession to be a period of negative change, from the point of view of American households the recession has ended. If we define it in terms of levels, the recession is not over and shows few signs of ending.

\section{The American Life Panel}


The American Life Panel (ALP) is an ongoing Internet panel survey of about 2500 persons operated and maintained by RAND Labor and Population. Panel members are recruited from respondents to the University of Michigan Survey Research Center's Monthly Survey (MS). The MS incorporates the long-standing Survey of Consumer Attitudes and produces the Index of Consumer Expectations. Each month, the MS interviews approximately 500 households, of which 300 are a random-digit-dialed sample and 200 are reinterviewed from the RDD sample surveyed six months previously. The MS survey is considered to have good population representation (Curtin, Presser, and Singer, 2005). At the end of an MS interview, respondents are asked to participate in the ALP; about $80 \%$ of MS respondents asked have agreed to participate. Those who do not have access to the Internet are provided with a Web TV (www.webtv.com/pc/), including an Internet access subscription with an e-mail account. Accordingly the sample does not suffer from selection due to a lack of Internet access. ${ }^{1}$ Poststratification weights are provided so that after weighting, the ALP approximates the distributions of age, sex, ethnicity, education, and income in the Current Population Survey. About once a month, respondents receive an email request to visit the ALP website to complete questionnaires that typically take no more than 30 minutes to finish. Respondents are paid an incentive of about $\$ 2$ per three minutes of survey time. Response rates are typically between 80 and $95 \%$ of the enrolled panel members, depending on the topic, the time of year, and how long a survey is kept in the field.

The ALP has conducted a large number of longitudinal surveys of its respondents, so that over time it has collected data on a very wide range of covariates. For example, ALP respondents have been asked about their financial knowledge, their retirement planning, and hypothetical questions designed to reveal parameters such as risk aversion. They have been given the Health and Retirement Study (HRS) survey instrument in modules one at a time over an extended period, so that we have responses to the wide range of HRS health queries and to the HRS cognitive battery. Most importantly, respondents were administered the HRS wealth module in November 2008, shortly after our first survey. ${ }^{2}$

A strength of the ALP is that it takes advantage of Internet technology. There is a short turn-around time between questionnaire design and the fielding of a survey, facilitating rapid responses to new events or insights. Thus, surveys can be operated at high frequency, reducing risk of missing events or the effects on households. This speed is in sharp contrast to the large household surveys such as the HRS where the time from planning to fielding can be as much as a year, and the time from fielding to data availability can exceed a year.

\section{The Financial Crisis Surveys}

The very large stock market declines in October 2008 prompted our first data collection. We designed a survey that was administered to the ALP in November 2008. The survey covered a broad range of topics, including various dimensions of life satisfaction, self-reported health measures and indicators of affect, labor force status, retirement expectations, recent actual job loss and chances of future job loss, housing, financial help (received and given and expectations

\footnotetext{
${ }^{1}$ This approach has been used successfully in the Dutch CentER panel for many years.

${ }^{2}$ As of this writing the ALP respondents have not yet been administered the HRS asset module a second time, so we are lacking two longitudinal observations on wealth over a crucial period of the economic crisis. Funding is pending for the second asset measurement planned for October 2010.
} 
about these), stock ownership and value (including recent losses); recent stock transactions (actual and expected over the next 6 months); expectations about future stock market returns (one year ahead, 10 years ahead); spending changes; credit card balances and changes in the amounts carried over; impact of the financial crisis on retirement savings; and expectations about future asset accumulation. We followed up with a second longitudinal interview in late February 2009 covering approximately the same topics.

In our first survey (November 2008) 73 percent of households reported they had reduced spending because of the economic crisis. These spending reductions are of substantial policy and scientific interest, and so there is considerable value in a careful measurement of the magnitude of the reductions. For example the welfare implications of the crisis depend partially on the reduction in consumption. Furthermore, because of the lack of knowledge of how spending responds to economic shocks at high frequency, it is important to establish the empirical connection between the triggering events and the magnitude of consumption reductions. The wide-spread spending reductions prompted us to re-orient the survey, expanding the collection of information on the components of spending.

Beginning with the May 2009 interview we established a monthly interview schedule to reduce the risk of recall error about spending and to collect data at high frequency on items such as employment, satisfaction, mood, affect and expectations. An objective was to permit detailed sequencing of events and their consequences. ${ }^{3}$

Each month we ask about spending in 25 categories during the previous month. These categories comprise about $70 \%$ of total spending. Every third month beginning in July 2009 we ask about spending during the previous three months on an additional 11 categories. Spending in these categories tends to be less frequent such as durables. Taken together, the monthly and quarterly surveys measure total spending over a three-month period. This three-month schedule of two shorter monthly surveys and a longer quarterly survey has continued to the present. ${ }^{4}$

These surveys have several unique aspects. The first and most obvious is that they are monthly panel surveys. This design permits the observation of the immediate effects of changes in the economic environment that cannot be captured in low frequency surveys via retrospection. A second unique aspect is our measurement of total spending on a monthly basis. This measurement reduces recall bias for high frequency purchases, yet because the surveys cover an entire year, this measurement also captures low frequency purchases. A third unique aspect is the elicitation of subjective probabilities at a high frequency. In this design both the determinants and the effects of subjective probabilities can be estimated. A fourth aspect is the elicitation of measures of mood and affect that respond quickly to economic events.

A total of 2,693 respondents participated in at least one of the 14 interviews from November 2008 through April 2010. The retention rate in the panel interviews has been high: 73.0 percent $(\mathrm{N}=1,966)$ responded to 10 or more interviews and 40.7 percent $(\mathrm{N}=1,096)$ responded to all 14 waves. The high retention rate is partly due to respondents being invited to continue to participate in the surveys even if they miss one or more of the interviews.

\footnotetext{
${ }^{3}$ To further reduce recall error the survey is only available to respondents for the first 10 days of each month except when the first day of the month falls on a weekend. Then the schedule is shifted by a day or two to accommodate staff work schedules. Thus state variables such as unemployment refer to approximately the first 10 days of a month, not the entire month.

${ }^{4}$ Information about the surveys is given in Appendix Table 1, including survey length, fielding schedule and response rates.
} 
In this paper we use data from 14 surveys covering the period November 2008 through April 2010. In the interest of maintaining an adequate sample size while at the same time basing results on an approximate panel sample, we admit into the sample for panel analyses respondents who missed at most four of the interviews. ${ }^{5}$

\section{Indicator of financial distress}

The main focus of the surveys is the effects of the financial crisis and the subsequent recession on the economic well-being of households and on their reactions to the economic shocks. As a summary measure of the immediate effects we say that a household is experiencing financial distress if the respondent and/or spouse is unemployed, or if the household is more than two months behind on mortgage payments (or in foreclosure), or if the value of the house is less than the amount of the mortgage. ${ }^{6}$ Table 1 shows in each wave the percentage of households in a panel sample that experienced financial distress. At the time of the initial survey $13.2 \%$ were in financial distress, and in the last survey in April 2010 16.8\% were in financial distress. We fit a regression line to these percentages and find an increase of $0.15 \%$ per month from the regression or $2.6 \%$ cumulative over 17 months. The second column of the table shows the cumulative measure; that is, the percentage of households that since the first interview in November 2008 were in financial distress in at least one of the surveys. By April 2010, 39\% of households had experienced financial distress. Thus the effect of the recession as measured by the fraction of households experiencing financial distress is not improving and it is widespread. This is to be expected because unemployment has not declined by any important amount and housing prices are approximately constant at levels much below their peaks in many cities.

Those with lower incomes are more likely to experience financial distress: the rate is $22 \%$ among households in the lowest income quartile but just 13\% in the highest income quartile (not shown). Younger people are more likely to be in households in financial distress: $23 \%$ of those aged 18-34 are in households in distress versus 8\% aged 60-69. ${ }^{7}$

\section{Housing}

Whether home owners have been affected by the large drops in home values, and how seriously they have been affected, depends on where they live and when they bought their home. Figure 1 shows Case-Shiller house price indices normalized to 100 in January 2003 for a 20-city

\footnotetext{
${ }^{5}$ Results that use the spending data are based on the third through the $14^{\text {th }}$ wave. A total of 2,623 respondents answered at least one of these 12 interviews. Among these, 48.2 percent $(\mathrm{N}=1,264)$ participated in all 12 waves. In the panel analysis of spending we include respondents who missed at most four of the 12 interviews. This restriction is met by 77.8 percent or 2,041 respondents. Thus the sample used for spending analyses is slightly different from the sample based on all 14 waves.

${ }^{6}$ This measure of immediate financial distress does not account for households who have fallen behind with rent payments because we did not initially collect this information. In later waves very few households report being more than two months behind with rent payments, so the omission is not expected to affect the results in a material manner. For longitudinal consistency of the measure of financial distress we excluded the event of "being behind with rent payments" from all waves.

${ }^{7}$ The statistics by age band and by income quartile are based on pooled observations from all waves. Income quartiles are based on households' average income computed over the entire survey period, stratified by marital status (single vs. couple households).
} 
average and for four representative cities, Phoenix, Los Angeles, Denver and Detroit. The 20city average peaked in May 2006 at about 50\% above its level at the beginning of 2003. Since reaching its peak it has fallen to about that initial 2003 level. The average conceals substantial intercity variation. As is evident in the graph, in Denver there was a moderate increase in housing prices, followed by a small decline, but this variation is not remarkable compared with historical price changes. In Los Angeles or Phoenix, by contrast, there were dramatic swings in home prices. However, the consequences of these price changes depend importantly on the date of purchase. Consider a family who bought a house in 2003. Although the value of the home is now below its 2006 peak of twice the purchase price, it is, nonetheless, at the 2003 level.

Provided the mortgage was reasonable in relation to family income, this family could have sound finances, even having paid off some of the principal on the loan. However, if a family bought at the top of the market with a small percentage down payment and a balloon loan, it would find itself with substantial negative home equity and increased mortgage costs which might be unaffordable.

It is noteworthy that substantial declines in housing prices are not limited to bubble markets. A family buying a home in Detroit in late 2003 would now see a decline in value of about $40 \%$. The downturn in the auto industry and the departure of other large employers, such as Pfizer, have taken their toll.

Our survey asks respondents about the value of their houses. These data have the virtue of being reports on the same house over time and of being nationally representative. Other commonly used data sources are based on recent actual property sales (possibly including refinanced properties) or in the Case-Shiller index confined to 20 large cities. Table 2 shows mean and median cross-section house values. We note that the ALP statistics are similar to those reported in the Federal Housing Finance Agency "Monthly House Price Indexes for Census Divisions and U.S. Purchase-Only Index" which is the only index available on a monthly basis. ${ }^{8}$ The reports from ALP respondents show a decline: Based on the regression of the log house value on calendar time, both the mean and median value declined by about $0.4 \%$ per month for a cumulative decline of about $7 \%$ over the 17 month period. This change does not account for inflation. While it does represent a decline in the most important asset of many households, it is not nearly as large as might be expected from the publicity about the crisis in the housing market. However, most of the losses in housing value were prior to our initial survey. Additionally only a subset of cities experienced very large declines in property values, but because of the prominence of the Case-Shiller Index they tended to receive considerable publicity which may have distorted expectations. This selective publicity may explain why respondents rate their local housing market more favorably than the housing market in the U.S. as a whole. ${ }^{9}$

We ask respondents about the value of their mortgages which allows us to calculate the percentage of owners with negative equity. These percentages of homeowners with negative equity are more representative of the population than those obtained from sources such as lenders or property records which are either incomplete or outdated. In Nov 2008, 5.6\% of homeowners owed more than their house was worth. By Feb 2009 this percentage had increased to 8.1\%.

\footnotetext{
${ }^{8}$ The "All Transactions Index," which uses sales prices and appraisals but is only available quarterly, shows somewhat higher appreciation than the purchases only index.

${ }^{9}$ This finding is based on questions asking respondents to rate on a 5-point scale the "housing market in the U.S. as a whole" and then the "housing market in [your] area." The fraction rating the U.S. housing market as fair or poor (85.9\%) is persistently 20 percentage points higher than the fraction rating the local housing market as fair or poor (65.8\%).
} 
After that there has been little trend in this percentage, hovering between 8 and 9 percent of homeowners in each wave whether measured in cross-section or in panel. ${ }^{10}$ Younger homeowners were much more likely to have negative home equity: $12.4 \%$ of homeowners under age 50 had negative equity compared with $5.2 \%$ among those 50 or older. Although negative home equity may not in itself lead to financial trouble, it makes the household vulnerable to other economic shocks such as unemployment. Unemployment tends to be greater among younger households.

A common measure of noncompliance with mortgage payments is being more than two months behind on payments. Table 3 shows that in panel data the number of such households reached a peak of 5\% in October 2009 and has fallen since then to 3.8\% in April 2010.

People with negative home equity do not keep up their mortgage payments as well as those with positive equity. Those with negative home equity are over 6 times as likely to be behind on their mortgage payments. Those falling behind are at great risk of losing their homes, lacking equity for possible refinancing. The observed negative equity positions therefore suggest further foreclosures in the future.

We asked respondents who were homeowners and had a mortgage whether they were being foreclosed. The fraction in foreclosure reached its peak in October 2009 with $2.7 \%$ and then declined. It was 1.3\% in January 2010, and 1.2\% in April 2010. Cumulating the foreclosures over time starting with the first survey in November 2008 through April 2010 we find that among those who had a mortgage at some time during this period, $4.8 \%$ had gone through foreclosure by April 2010. ${ }^{11}$

\section{House price expectations}

Respondents are asked about expectations of price appreciation in the form of a subjective probability as follows:

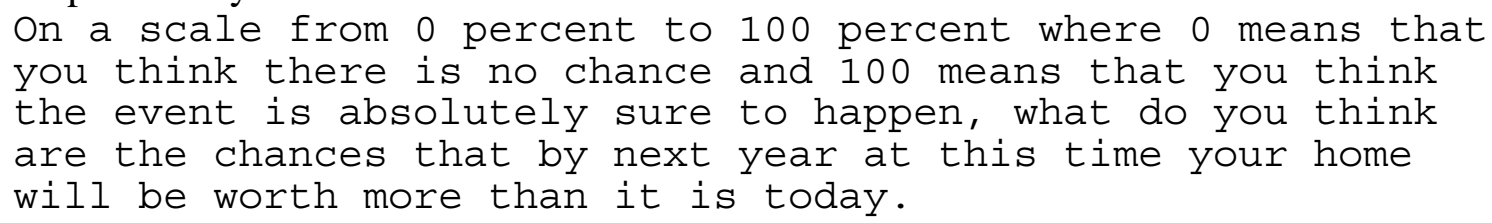

In addition the quarterly surveys ask the same question but with a time horizon of five years.

Table 4 shows the average subjective probabilities. The most notable feature of the results is the very pessimistic expectations. The mean and median subjective probability of a gain over the next 12 months was about 40\% in May 2009 through July 2009, indicating that, according to respondents' beliefs, a decline in prices was more likely than a gain in prices. Households holding that view are likely to be conservative in spending or in borrowing against the value of their house. These expectations are very much at odds with historical frequencies. Based on changes in the monthly house price index of the Federal Housing Finance Agency "Monthly House Price Indexes for Census Divisions and U.S. Purchase-Only Index" the

\footnotetext{
${ }^{10}$ Among homeowners with a mortgage about $12 \%$ had negative equity.

${ }^{11}$ In cumulating the observations of experiencing foreclosure over time we include respondents who have missed some waves.
} 
estimated probability of a gain in house value over one year would be $88 \% .^{12}$ One explanation for this discrepancy is that the past offers little guidance to the future due to the exceptional nature of the recession. A second, more general explanation, is that expectations of future price changes are dependent on recent price changes as has been found for stock market expectations (Hurd, 2009).

One-year expectations increased between February 2009 and May 2009. Between May 2009 and January 2010 housing prices were approximately constant (Table 2) and one-year average expectations were also approximately constant. But in April 2010 the median probability of a one-year gain declined to just $30 \%$, possibly reflecting recent declines in reported housing values.

While five-year expectations are greater than 50\% they still show considerable pessimism and are at odds with historical price changes: the historical estimate based on the "Monthly House Price Indexes" is $100 \%{ }^{13}$ That is, in every five-year interval since 1992 (taken monthby-month) house prices have increased. In distinction to one-year expectations, five-year expectations were lower in April 2010 than in February 2009. Apparently people have become somewhat more optimistic about the short-run as measured by the one-year expectations while at the same time they have become more pessimistic about the long-run as measured by the fiveyear expectations.

\section{Spending}

\section{Spending expectations}

In normal times, most people should expect approximately stable spending over a six month horizon. To the extent that they anticipate changes, most of the changes would be positive because spending increases with age until old age. In addition nominal spending should increase over time both because of inflation and because of increases in incomes. However, in November 2008 just $8 \%$ of respondents expected an increase in spending over the next six months whereas about 20\% expected a decrease (Table 5). The low point was reached in February 2009 where $22 \%$ expected a decrease. The expectations of a decrease likely resulted from pessimism about the stock market and the housing market, heightened concerns about unemployment, and about the vulnerability of income. By the metric of expected spending change, the low point of the recession was reached in about February or March 2009 which coincided with the low point of the stock market and a cessation in the decline in house prices.

Expectations are now stable with more expecting an increase than a decrease. This does not necessarily mean that people have become more optimistic about the future course of the economy: it could be that spending has been reduced to a level such that people do not expect that further reductions are necessary.

There is a remarkable match between expectations of spending change and recollections of actual change. Respondents were asked in July 2009 about whether they had reduced spending over the preceding six months. Table 6 shows expectations of spending change

\footnotetext{
${ }^{12}$ Calculated as the percentage of 12-month intervals over which the housing price index increased between January 1, 1991 to November 1, 2009.

${ }^{13}$ Calculated as the percentage of five-year intervals over which the housing price index increased between January 1, 1991 to November 1, 2009.
} 
collected in February 2009 with recollections of spending change collected in July 2009 in panel. Although the temporal comparison is not completely exact, the expectations were very accurate when they are compared with recollections.

\section{Self-reported spending changes}

In Wave 1, 73\% of respondents said they reduced spending because of the financial problems in the economy. In Wave 2, 30\% said spending was lower compared to spending in November 2008. We found little variation in reported spending reductions by age and income except that fewer reduced spending among those aged 60+ and fewer reduced spending in the highest income quartile. Many respondents reduced spending on health care such as doctor visits and prescription drugs (self-reports): in wave 1, 22\% said they had reduced such spending over the last 6 months and in wave 2, 25\% since the November 2008 interview. These reductions in health care spending may lead, of course, to negative health consequences over the longer term.

In the climate of the recession it is natural to think that reductions in spending are due to reduced economic resources or to pessimistic expectations about future economic resources such as an increased likelihood of unemployment and the associated reduction in income. But spending reductions could also reflect changes in "needs" such as changes in family composition. Similarly spending could increase because of an unanticipated increase in resources or because of increased requirements for spending due to, say, higher out-of-pocket spending for health care. To separate changes in actual or anticipated resources from changes in needs, we asked about the reasons for spending changes.

Among those who reported an increase in spending we find a combination of an increase in economic resources and an increase in spending requirements. Of particular interest is that in the 2009 interviews 24\% of households reported an increase due to higher required mortgage payments; this percentage declined to $19 \%$ in the 2010 interviews. However, there was a substantial decline in the percentage reporting an increase in spending because of increases in economic resources or better employment.

Reasons for Increase in Spending among those Reporting an Increase.

Percent indicating "very or moderately important"

\begin{tabular}{lcc}
\hline & $\begin{array}{c}\text { Earlier quarterly } \\
\text { interviews } \\
\text { (Feb09, Jul09, Oct09) }\end{array}$ & $\begin{array}{c}\text { Later quarterly } \\
\text { interviews } \\
\text { (Jan10, Apr10) }\end{array}$ \\
\hline increase in income or wealth & 47.1 & 34.7 \\
better actual employment & 32.9 & 20.7 \\
higher required mortgage payments & 24.1 & 18.6 \\
other increased spending needs & 86.1 & 80.3 \\
\hline Percent of respondents reporting increase in & & \\
spending since previous quarterly interview & $11.7 \%$ & $13.0 \%$ \\
$N$ & $648-654$ & $517-522$ \\
\hline
\end{tabular}

Note: Respondents could check more than one reason.

Among those who reported a reduction in spending, about $80 \%$ cited a need to reduce debt and $68 \%$ cited a reduction in income. According to the self reports, the decline in stocks and in the 
house value directly led to a reduction in spending. There was little change in these percentages between the earlier and later waves. However, the overall percentage of households that reduced spending was lower in the 2010 interviews than in the 2009 interviews. Possibly prior reductions in spending were deemed sufficient by some households so that further reductions were not necessary in the later waves. But the lower percentage of households is also consistent with the improvement in expectations reported in Table 5, and with stabilized conditions.

Reasons for a Decrease in Spending among hose Reporting a Decrease.

Percent indicating "very or moderately important"

\begin{tabular}{lcc}
\hline & $\begin{array}{c}\text { Earlier quarterly } \\
\text { interviews } \\
\text { (Feb09, Jul09, Oct09) }\end{array}$ & $\begin{array}{c}\text { Later quarterly } \\
\text { interviews } \\
\text { (Jan10, Apr10) }\end{array}$ \\
\hline need to reduce debt & 81.1 & 78.6 \\
reduction in income & 68.5 & 67.7 \\
change in employment status & 46.2 & 45.6 \\
decrease in value of stock holdings & 35.0 & 39.7 \\
decrease in housing value (homeowners only) & 46.0 & 48.8 \\
\hline Percent of respondents reporting decrease in & & \\
spending since previous quarterly interview & $26.1 \%$ & $16.8 \%$ \\
$N$ & $1656-1660$ & $656-658$ \\
\hline
\end{tabular}

Note: Respondents could check more than one reason.

\section{Actual spending}

Because of the large and wide-spread declines in spending reported in the first two surveys we began in the May 2009 interview to ask detailed questions about amounts spent in the preceding month. Our strategy was to ask about spending in 25 categories that are purchased at high to middle frequency every month. Then, every three months we asked about the purchase over the past three months of 11 more infrequently purchased categories. With possibly a few minor exclusions the total of the three monthly surveys and the quarterly survey add to total spending over the quarter.

The 25 categories queried in the monthly surveys are shown in Appendix Table 2 grouped as they would have been displayed. The grouping by broad types of spending or by frequency of spending is meant to facilitate placement of reported amounts in the proper category: Respondents are sometimes unsure about category placement and they are helped by seeing other possibly relevant categories. The grouping should reduce the risk of either omission or double counting. For example, the following categories were displayed at the same time because they are associated with household operations.

\begin{tabular}{|l|}
\hline Mortgage \\
\hline Rent \\
\hline Electricity \\
\hline Water \\
\hline Heating fuel for the home \\
\hline
\end{tabular}




\begin{tabular}{|l|}
\hline Telephone, cable, Internet \\
\hline Car payments: interest and principal \\
\hline
\end{tabular}

A major innovation was the development of a "reconciliation" screen. Outliers are a problem in self-administered data collection such as Internet interviewing because there is no interviewer to question extreme values. Therefore, we designed a new strategy for the ALP to help with outliers: following the queries about spending last month on the 25 items we presented the respondent with a summary table which listed the responses and added them to produce the implied monthly spending total. The respondent was invited to correct any items. This produced two very favorable results. Item nonresponse was reduced from an already low level to a trivial level: in the initial survey of spending (May09) the maximum item nonresponse (rent) was reduced from $2.6 \%$ to $0.7 \%$, and in the following wave the maximum item nonresponse (again rent) was reduced from $2.7 \%$ to $0.9 \%{ }^{14}$ The maximum rate of item nonresponse over all 25 items following the summary table was $0.8 \%$ in May09 and $0.9 \%$ in June09. This means that almost no imputation for missing values is required. The second favorable result was a sharp reduction in outliers. Combining both waves, the standard deviation of total spending (on the 25 items) was reduced from $\$ 14,045$ to $\$ 5,624$. The reduction was the result of a small number of revisions, on average $2.5 \%$ of responses in each category of spending. However, eliminating outliers in each category has an enormous impact on standard errors of the total that is constructed as the sum of these 25 spending categories. The importance of a reduction of this size can be seen directly in standard errors in models that explain spending: roughly speaking the standard errors on estimated coefficients in regression models will be reduced by a factor of about 2.5, making estimates that were formerly marginally significant, highly significant. See Appendix Table 4 for more details.

\section{Comparison with the Consumer Expenditure Survey}

The CEX has the most authoritative survey measure of spending at the household level, and so we would like to compare annual spending in the CEX with annual spending in our survey. However, the latest published tables from the CEX cover the year 2008, which, even after adjusting to 2009 prices, will make the comparison with ALP spending data for 2009 inexact: based on the trends in spending in our survey to be discussed below and in the decline in spending in the National Income and Product Accounts, spending in 2009 was likely lower than spending in 2008. We therefore expect that the price-adjusted level from the CEX for 2008 will be higher than our more recent spending measure.

In the ALP we calculate spending over a year by summing spending in the second, third and fourth quarters of 2009 and in the first quarter of 2010. Spending in each quarter is the sum of spending on the 25 items that are measured each month plus the 11 additional items that are measured every quarter.

Average spending in 2008 as reported in the CEX was \$44,721 (in 2009\$); average spending in the ALP was $\$ 41,723$. Thus ALP spending is $93 \%$ of CEX spending. In our view

\footnotetext{
${ }^{14}$ In the reconciliation screen, missing items were filled with zeros, and in a very few cases respondents corrected these zeros to positive values. The item nonresponse rates are calculated under the assumption that the remaining zeros were affirmed by the respondent. The remaining missing values are due to some respondents quitting the survey before reaching the spending questions.
} 
these levels are remarkably similar, particularly because the CEX levels for 2009 will likely be lower than the 2008 levels.

\section{Trends in spending}

Table 7 has average and median spending in the 25 categories both in cross-section and in panel. There is almost no difference between the cross-section medians and the panel medians both with respect to levels and trends, and the only substantive difference between the crosssection and panel means is in the initial wave. All show a reduction in spending between April 2009 (as recorded in the May survey) and March 2010 as recorded in the April survey. The rates of decline based on the regression of log spending on calendar time range from about 0.5 percent per month to one percent per month for a cumulative decline of 5-10\%. These, of course, are substantial changes in spending over a short time period. Were income constant, the household saving rate would have increased considerably. Except for the decrease in spending in the first four months, the time pattern is unclear: a minimum was reached in January 2010 but the data do not show a definite pattern of increase since then.

Certain components of spending are of interest as well as the total. Table 8 shows spending on food, disaggregated into food purchased for consumption at home (food in) and food purchased away from home such as in restaurants (food out). As measured at the mean, spending for "food in" declined at about $0.5 \%$ per month for a total decline of $5.5 \%$ whereas spending for "food out" declined at a somewhat higher rate. When measured at the median, however, the differences are greater: median spending for "food in" did not decline at all whereas the cumulative decline for "food out" was 33\%. Apparently households substitute for (cheaper) eating at home. It is noteworthy that the declines for total spending on food were close to the declines on total spending on the 25 categories (Table 7). Although food is a necessity, the substitution between spending on "food in" and "food out" led to approximately constant budget shares on total spending for food.

Table 9 has spending on two categories of health care: prescription drugs and health care services such as doctor visits. The decline in spending on the two components and on the total was substantially greater than the decline in spending on the 25 categories, indicating that the budget share declined. The decline is particularly sharp if spending in March 2010 (April 2010 survey) is excluded: for example, the median in February 2010 was just half of the level in April 2009. Because spending on health care is protective against future health declines, economizing in this way has potentially long-term negative consequences.

\section{Credit cards}

Respondents were asked about ownership and use of credit cards. Table 10 shows that the ownership of credit cards declined by about $0.2 \%$ of households per month for a cumulative decline of 2.8 percent of households. At the same time the percentage of credit card holders that paid the balance each month and escaped interest charges increased by about 3.8 percent of households. However, credit card debt conditional on carrying debt over from one month to the next increased by about $\$ 1,000$ or $25 \%$. Averaged over the entire population (not just those that carried debt), by February 2010 credit card debt on which interest is assessed had increased by $\$ 500$. At an interest rate of $16 \%$ this is an increase in monthly interest payments of $\$ 80$ per month or $\$ 960$ per year. 


\section{Stock Market}

Over the past 20 years defined contribution plans have become an increasingly common form of employer-provided pension plans. As a result the fraction in the population holding stocks, even if indirectly in their pension plans, has increased over the years (Curcuru et al. (2009)). The large declines in the stock market at the onset of the financial crisis likely threatened retirement security, especially of those near retirement. We asked in the first two waves whether the "recent financial problems in the economy reduced the value of [the respondent's (and/or spouse's)] retirement savings," by how much and whether respondents actively changed how their retirement savings were invested. About 28\% said that they did not have any retirement savings, a response that is naturally most common among younger households who have not had much opportunity to accumulate retirement savings. ${ }^{15}$ Among those with retirement savings, 71 percent reported losses due to financial problems in the economy. This percentage varies substantially by socioeconomic status as measured by household income averaged over the entire survey period: in the lowest income quartile 47 percent reported losses, and in the highest income quartile 93 percent reported losses in their retirement savings.

The self-reported magnitude of the losses was about 20\% at the median in November 2008 and about 30\% both at the mean and median by the time of our second interview in February 2009. Since November 2008 the stock market continued to decline until its low point in March 2009 when it was about 32\% below its early November level.

Prior research suggests that households rarely rebalance their retirement savings portfolios. See, for example, Agnew et al. (2003), Ameriks and Zeldes (2004) or Mitchell et al. (2006). However, these findings are based on administrative data from retirement plan providers which only record partial retirement asset holdings such as Vanguard proprietary data. Furthermore, the findings come from "normal" times when there is no large event prompting investors to rebalance their portfolios. We asked households about "active changes in how [their] retirement savings are invested." With this question wording we elicit changes in households' entire retirement assets (not just one part of their portfolio). $21 \%$ of those with retirement savings reported in the February 2009 survey having made "active changes to how retirement savings are invested" since the November interview. This seemed like a large fraction over a short period of time-just three months - even though we do not know what this fraction would be in normal times. Such investment moves may have a large impact on the long term performance of portfolios - either through locking in losses by getting out of the stock market in response to large declines, or through creating the potential for large gains by getting into the stock market at that time. Beginning in the May 2009 survey we asked detailed questions about asset allocation in retirement accounts with special emphasis on whether changes involved increasing or decreasing stock market exposure. The objectives of these questions are twofold: first, we wanted to find whether the large fraction of respondents reporting "active changes" to their retirement investment allocations would be verified by quantitative measures of investment activity. Second, we wanted to quantify the amount of asset reallocation.

\footnotetext{
${ }^{15}$ Among those under the age of 35, half report not having any retirement savings, while just $5 \%$ of those age 70 and older reported no retirement savings.
} 
As of May 2009, 64.5 percent of households in our sample had an IRA, 401k, KEOGH or similar retirement saving accounts. $28.6 \%$ of retirement account holders had made a change in the investment of new funds and/or the allocation of old balances since the beginning of October 2008, that is, since the beginning of the financial crisis. Among retirement account holders who also responded to wave 1 or wave 2 of the survey the fraction reporting having made "active changes" to their retirement savings was 28.0 percent.

About 10 percent of retirement account holders changed the investment allocation of new contributions. The fraction of respondents that increased the amount of new funds allocated to stocks is similar to the fraction that decreased the amount of new funds allocated to stocks (4.6 percent vs. 5.2 percent, respectively). However, with respect to reallocations of account balances we find that a much larger fraction decreased their exposure to stocks (16.4 percent) than increased (6.3 percent). ${ }^{16}$ Overall respondents decreased stock holdings in retirement accounts. Under unchanging expectations finance theory would call for rebalancing, an increase in stock holdings following the long period of losses. The most obvious explanation for this discrepancy is that expectations were not determined by historical averages, but by more recent experience, leading to considerable pessimism about the future course of the stock market.

Percent of households making changes to retirement accounts (among holders), October 2008 to May 2009, N=1,513

$\begin{array}{lr}\text { Allocation of new funds } & 4.6 \\ \text { increased amount to stocks } & 5.2 \\ \text { decreased amount to stocks } & \\ \text { Allocation of balances } & 6.3 \\ \text { increased amount in stocks } & 16.4 \\ \text { decreased amount in stock } & 3.0 \\ \text { Sold all stocks in retirement accounts }\end{array}$

\section{Stock market expectations}

We asked about expectations of gains in the stock market in the form of the subjective probability that a broad measure of the stock market such as the Dow Jones Industrial Average would be higher in one year than today. ${ }^{17}$ We also asked about a gain over a 10 -year horizon. The one-year subjective probabilities exhibit considerable pessimism: the average subjective probability is just 40\% (Table 11). The historical record for the Dow is that in $70 \%$ of the oneyear periods since January 1, 1970 the stock market had a gain, so that an average subjective probability based on the historical record should be $70 \%$. The median probability of a gain was $50 \%$ in most months which implies that the distribution had a fairly fat left tail; that is, a

\footnotetext{
${ }^{16}$ Bilias et al. (2010) compare trends in stock market participation before and after the 2000 stock market downturn and find that in the first years following the downturn nonparticipants were less likely to enter the stock market while there was no sign of substantially higher exit rates. Their analysis of trading behavior is restricted to stock holdings outside of retirement accounts.

17 The question has the same form as the question about housing price expectations.
} 
considerable number of respondents assign a small probability of a gain. The average subjective probability of a gain over a 10-year horizon began at a considerably higher level, almost $61 \%$, but then in distinction to the probability of a gain over one year, it has declined by about 10 percentage points. The historical probability calculated from all 10 -year periods since Jan 1 , 1970 is $93 \%$.

While the subjective probability of a short-term gain has been approximately constant, the subjective probability of a long-term gain has decreased substantially, and the average probabilities are much below their historical averages. Thus the stock market subjective probabilities are similar to the housing price subjective probabilities in that both show a narrowing of the difference between the long horizon and short horizon probabilities. One interpretation is that people are quite pessimistic about the long-run prospects of the economy. Under this interpretation households are likely to be conservative in their spending decisions.

\section{Health and Affect}

A cost of the financial crisis in terms of well-being is its effect on the emotional and physical health of the population. Respondents were asked to rate their satisfaction about several aspects of their lives, about their health and about indicators of happiness or depression. Table 12 shows the percentage of respondents who affirmed the lowest two categories on a five point scale about life satisfaction, and income and economic satisfaction; that is, it shows the percentage who were "dissatisfied" or "very dissatisfied." 18 For life satisfaction, just $7.1 \%$ of respondents were dissatisfied or very dissatisfied in May 2009. Since then the percentage has slowly increased reaching a maximum in March 2010. Dissatisfaction with income or with the economic situation is considerably higher with about one-third of respondents expressing dissatisfaction. Except for the initial drop in May 2009, there has been no noticeable trend.

Table 13 shows the percentage of respondents who affirmed the bottom categories of self-rated health and of scales related to happiness and to depressive symptoms. There are five categories of self-rated health and the table shows the percentage who rated their health as fair or poor. ${ }^{19}$ That percentage initially declined from 16.0\% in November 2008 to 13.8\% in May 2009. Since then the percentage has shown little trend. The next column of the table shows the percentage that feel worn out (during past 30 days) all of the time, most of the time, or a good bit of the time. ${ }^{20}$ There has been no trend in mood according to this measure. The results about happiness (during the last 30 days) show the percentage who were happy none, a little or some of the time. There was improvement between November 2008 and June 2009, but little change until the last several interviews when the percentage increased. About one-third of respondents reported moderate to extreme difficultly sleeping in November $2008{ }^{21}$ There has been a substantial reduction in that percentage. Problems with depression have mostly been unchanging.

\footnotetext{
18 The scale is very satisfied, satisfied, neither satisfied nor dissatisfied, dissatisfied, very dissatisfied.

${ }^{19}$ The self-rated health scale is excellent, very good, good, fair and poor.

${ }^{20}$ The scale for "worn out" and for "happiness" is all of the time, most of the time, a good bit of the time, some of the time, a little of the time, none of the time

${ }^{21}$ The scale for difficulty sleeping is none, some, moderate, severe, extreme.
} 
Overall, the results for health and affect mainly indicate improvements from November 2008 to May 2009. In the subsequent months there has been much less improvement and in some cases a worsening.

\section{Retirement}

Our survey has not been in the field long enough to observe any substantial number of actual retirements. However, we ask respondents about their subjective probability of working past age 62 (P62) and past age 65. These subjective probabilities have been asked in the HRS for many years and they have been shown to be predictive of actual retirement (Hurd, Reti and Rohwedder, 2009). They have an advantage over data on actual retirement because changes in the subjective probability control for individual fixed effects such as unmeasured permanent taste differences. Such fixed effects are difficult to control when using actual retirement data.

We expect that the financial crisis and subsequent recession could have two opposing effects on retirement. In theory, the decline in stock values should have delayed retirement because of the unexpected wealth loss. However, our survey had not yet been fielded during the period of the greatest stock market losses when $P 62$ would have increased the most. The second effect on retirement is the worsening of the labor market, and particularly the difficulty of finding a job following unemployment in the older population. The labor market effect would likely lead to a reduction in expected retirement age. The net effect is an empirical matter.

Table 14 shows average values of $P 62$ in cross-section for the population 45-61 and for selected subpopulations. For the 45-61 year-olds, whether working or not, the average value of P62 was approximately constant from February 2009 to January 2010, but then dropped by 3.3 percentage points in April 2010. To put that change in perspective, the labor force participation rate of the older population has been increasing during the 1990s and particularly in the 2000s: in 2003 the rate among those $60-64$ was $51 \%$, and the rate was $54.1 \%$ in 2008 . The increase over five years was 3.1 percentage points about the same as the three-month decline in $P 62$. If the actual labor force participation of ALP respondents is well-predicted by P62, these data suggest a sharp reversal of the trend toward higher participation. ${ }^{22}$

The level of $P 62$ is higher among those 45-52 than among those 53-61 because some in the older age group have already retired. Although the decline in P62 between January 2010 and April 2010 occurred in both age groups, disaggregation by work status shows a remarkable difference between the two groups. In the older age group the overall trend as measured between February 2009 and April 2010 was moderately negative among those working and moderately positive among those not working. In the younger age group the trend was also negative among those working, but it was sharply negative among those not working. The contrast is greatest between July 2009 and April 2010: P62 was approximately 13 percentage points lower among the younger non-workers but two percentage points higher among the older non-workers. This decline suggests in increase in pessimism about the future course of the labor market, which is likely due to the persistence of high rates of unemployment.

\footnotetext{
${ }^{22}$ Whether $P 62$ will be a good prediction of labor force participation at age 62 will depend on the future course of the economy. Should job prospects improve, $P 62$ will likely increase and actual realized labor force participation be higher than $P 62$ measured currently
} 


\section{Unemployment}

We ask respondents about their current labor force status. As shown in the following table, they can check a number of options one of which is "unemployed."

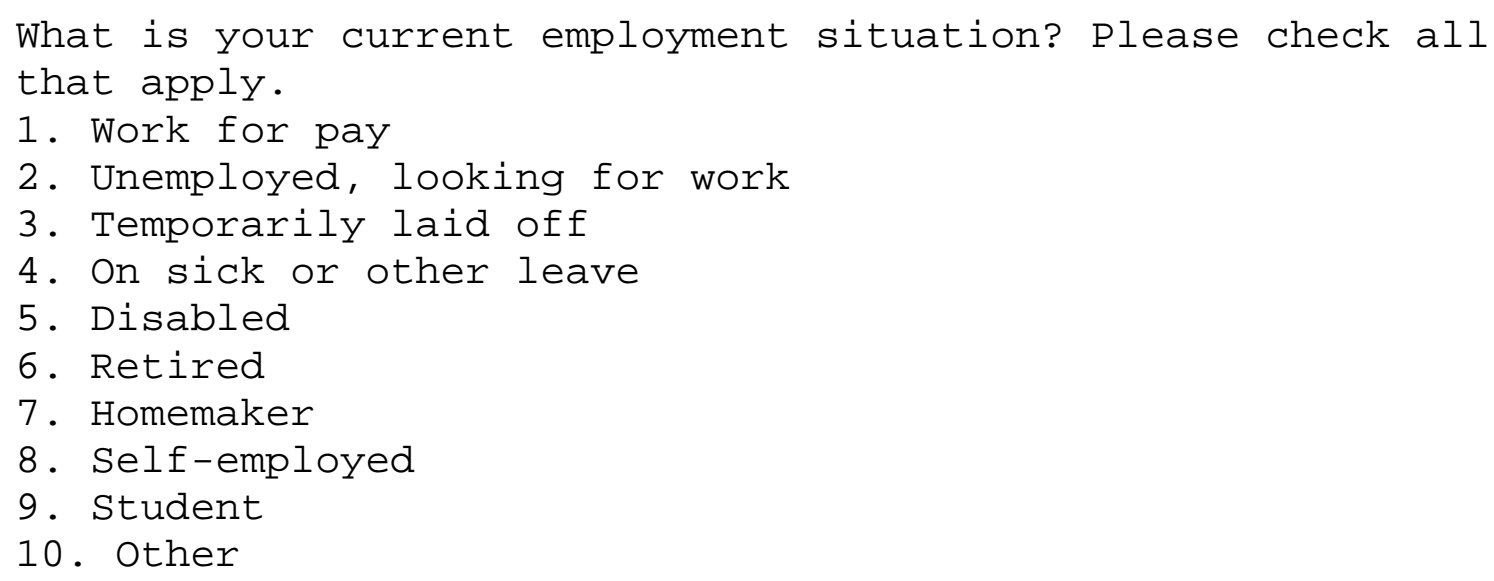

Respondents are employed if they check 1, 4 or 8 . They are unemployed if they check 2 or 3 . The unemployment rate is the number unemployed divided by the sum of the unemployed and employed.

Because the status of being unemployed is subjective, rather than based on specific objective activities related to job search as in the Current Population Survey (CPS), our measure should include those who consider themselves to be unemployed but have not performed any of those activities. Our measure generally tracks national statistics which come from the CPS but it is higher because it includes some who are not actively looking for work.

We also ask about the labor force status of the spouse so that we are able to calculate a household unemployment rate in the case of couples.

\section{Coping with Unemployment}

For most households, unemployment is associated with a substantial loss in income. There are many different ways in which households might cope with this reduction in income. Broadly speaking the household may alter its spending or it may seek replacements for the loss of income. Which ones a household relies on depends on the household's circumstances. Beginning with the May 2009 survey (wave 3) we asked follow-up questions in case a household (respondent and/or spouse) experienced unemployment over the last three months to find out how affected households deal with the loss in income. Table 15 shows the distribution of responses. "Reducing spending" is by far the most wide-spread response used by 85 percent of households who experienced unemployment. $46 \%$ reduced the amount going into savings. Not paying bills on time is also common.

Households may also undertake activities to replace the income lost from unemployment such as the application for and receipt of unemployment benefits or the support from the extended family. Table 16 shows the distribution of responses by those who experience unemployment or by those whose spouses experience unemployment.

About one-third of households took money out of savings, and 27\% received financial help from family or friends. Forty percent received unemployment benefits. The low level of 
benefit receipt is likely due to a combination of variation in how fast laid off workers decide to claim benefits, lack of qualification for benefits, and failure to take up benefits. ${ }^{23}$

We distinguish two types of labor supply response to unemployment: efforts by the respondent or by the spouse (as reported by the respondent) in reaction to own unemployment; efforts by the respondent in reaction to the spouse's unemployment and by the spouse in reaction to the respondent's unemployment. A labor supply response was far from universal: to own unemployment about $13 \%$ of respondents took up a temporary job, and about $9 \%$ of spouses who became unemployed took up a temporary job. In addition, about 5-8\% of married persons began to work or increased hours after their spouses became unemployed. A likely reason for these rather small labor supply responses is that we do not distinguish between short-run and long-run responses: many of the unemployed have been unemployed for just a few weeks and a maximum of three months to be asked these follow-up questions. It is likely that as the unemployment duration increases the labor supply response will increase.

\section{Unemployment Expectations}

Expectations about unemployment as well as actual unemployment should be an important component in a household's determination of spending. To track expectations about unemployment we asked workers about their subjective probability of becoming unemployed in the next 12 months. Table 17 shows the average probability in successive cross-sections. The average probability began at about 20\% and increased to almost 22\% in May 2010. If each person accurately assessed his or her probability the twelve-month actual fraction of workers who would experience unemployment would be $22 \%$. There has been some improvement since then: based on a fitted regression line the average probability decreased by about 2.2 percentage points over the 18 months of our surveys. The decline is likely due to improvements in the housing and stock markets and to the stabilizing of the actual unemployment rate and the subsequent modest reduction.

We can compare the expected percentage who will be unemployed over 12 months with the realized percentage who actually became unemployed by tracing actual unemployment at the individual level in the monthly surveys. The within-person comparison shows that $19.4 \%$ experienced unemployment between November 2008 and October 2009 (Table 18). Their average subjective probability reported in November 2008 was 20\%. Thus workers predicted quite accurately on average what their unemployment experience would be. In later waves workers predicted more unemployment than what was experienced: for example, in May 2009 the average subjective probability of unemployment was $22 \%$ and the actual was $17 \%$.

\section{Unemployment and home ownership}

Table 19 shows the relationships among home ownership, unemployment and mortgage delinquency. In the entire population some $65.5 \%$ own a home, but the ownership rate is just 46.4\% among the unemployed. Despite the lower ownership rate, about $3.5 \%$ of the unemployed are in arrears on their mortgage payments versus $1.7 \%$ in the population. Conditional on owning a home, the unemployed are more likely to have a mortgage (79\% versus $75 \%$ ), and, conditional

\footnotetext{
${ }^{23}$ Questions about responses to unemployment are asked only of workers who lost a job some time over the previous three months so that the unemployed who are slow to take up benefits are not recorded as receiving them.
} 
on having a mortgage, they are more likely to be delinquent (more than two months behind on payment) on their mortgage (10\% versus 3\%).

Households experiencing unemployment are much more likely to have negative home equity than those who are not. Among homeowners with a mortgage about $12 \%$ have negative equity compared with $17 \%$ of those unemployed. Although negative home equity does not necessarily imply financial difficulties, the combination with unemployment does, as then the household risks an inability to make its mortgage payments, and possible loss of the home.

\section{Unemployment and spending}

Prior research has found mixed results with respect to spending changes following unemployment, but those studies were based on very different types of data. ${ }^{24}$ Our method is to classify people according to whether they are initially employed or unemployed. Then we study changes in spending associated with month-to-month transitions between those states. Table 20 shows those transitions over the May 2009 to April 2010 waves. Thus 14,053 respondents were employed in adjacent waves. Among those respondents average spending in the initial wave (wave t) was $\$ 2,551$; spending was lower in the following wave (wave $t+1$ ) by $1.8 \%$ Median spending was lower than mean spending, and it declined by about $0.7 \%$ between waves $t$ and $\mathrm{t}+1$. The last column shows the median of the household changes and it shows a decline of 0.3\%. 350 persons transited from employed to unemployed. Both mean and median spending by their households was lower even when employed (wave t) than spending by households who were employed in both waves. Mean spending in households that became unemployed declined by $3.5 \%$. Median spending increased by $2.4 \%$ but the median of household level changes was negative $2.8 \%$. At least according to two of the measures, the transition into unemployment was accompanied by a greater decline in spending than the transition from employment to employment. However, the transition from unemployment to employment was also associated with a decline in spending whereas we would have expected an increase. Part of the reason for this discrepancy is that spending is measured over the prior month during which the respondent was unemployed for at least part of the time. Additionally the adjustment to the new economic situation may require some time so that it would appear in later waves.

Table 21 presents some alternative evidence about the effects of job loss on spending. We asked in the quarterly surveys (July 2009, October 2009, January 2010 and April 2010) whether over the previous three months the respondent or spouse had lost a job that he or she wanted to keep, and if so, whether any income was lost in association with the job loss. The table shows spending in the month at the beginning of the recall period (wave t-3) and in the current month (wave t): thus spending changes are over three months. This comparison is likely more valid than Table 20 because most would have been unemployed during the month when spending was measured.

Among those who did not report a job loss, spending declined at the mean by $1.7 \%$ over the three month period or about 0.6 percent per month, and at the median by $1.2 \%$ or about $0.4 \%$ per month. Particularly when measured at the median the decline in spending was substantially higher among those who lost a job and lost income: the median decline was $10.7 \%$.

\footnotetext{
${ }^{24}$ Prominent studies using panel data include Gruber (1997), Gruber (2000), Stephens (2001), Bentolila and Ichino (2008) and Sullivan (2008), which tend to find mixed evidence with regard to the size of the response of spending to shocks to income and employment.
} 


\section{Unemployment and Health and Affect}

Because of stresses associated with job loss we expect that those who became unemployed would exhibit symptoms of stress such as sleeplessness. The unemployed would also have a reduction in several domains of satisfaction about life. Figure 2 shows the change in the percentage giving negative reports about these and other aspects of feelings and lives according to their labor market transition between two adjacent waves. ${ }^{25}$ The upper left graph shows that among those who were employed in two adjacent waves about eight percent were dissatisfied or very dissatisfied with their lives and that in the follow-up wave the percent dissatisfied declined slightly. Among those who became unemployed, the percentage expressing dissatisfaction with life was higher even when employed, and it increased by about three percentage points in the follow-up wave. Among those who transitioned from unemployment to employment the percent expressing dissatisfaction with life declined by half, and among those unemployed in two adjacent waves dissatisfaction with life was very high in both waves.

It is notable that in the graphs about economic and income satisfaction, the fractions dissatisfied are much higher than with respect to life satisfaction: even among those employed in two adjacent waves 30-35\% expressed dissatisfaction. The changes accompanying employment transitions have the same pattern as those with respect to life satisfaction.

In general the graphs for sleeplessness, depression, being worn out and feeling happy show the same pattern. The exception is self-rated health: those employed in adjacent waves have better health than those unemployed in any wave, but there is no systematic relationship with employment transitions. Most likely changes in self-rated health take longer to materialize following a transition. ${ }^{26}$

\section{Unemployment and Health Insurance}

A particular concern is that those who become unemployed may lose health insurance, exacerbating the economic impact of unemployment. We ask respondents about health insurance coverage which may come from own employment or a spouse's employment. Table 22 shows how such coverage is related to employment transitions by showing coverage rates as a function of the transition from one month to the next. For example, 3,231 single persons are observed to transit from employed to employed. Of them, $82.8 \%$ had health care insurance in the initial wave and $82.9 \%$ had such insurance in the succeeding wave.

Single persons who became unemployed were initially much less likely to have health insurance even when employed, and the coverage rate declined by about 23 percentage points on becoming unemployed. This decline is much sharper than for married persons where it was just three percentage points. Part of the difference is, of course, due to spouse coverage. Part may also be due to the greater economic resources of couples where they may be able to afford COBRA coverage. In addition, the impacts in the table are immediate impacts: on average newly unemployed respondents had only been unemployed for two weeks as of wave $t+1$, and over longer periods the fraction lacking insurance may increase. For example, some employers may provide temporary coverage as part of a separation package, but this coverage is not permanent.

\footnotetext{
${ }^{25}$ The explanation of the scales is given in connection with the discussion of Tables 12 and 13 .

${ }^{26}$ The longer-term dynamics of the measures of health, affect and mood undoubtedly show different quantitative relationships than the one-month changes shown here.
} 


\section{Conclusions}

The economic problems leading to the recession began with a housing price bubble in many parts of the country and a coincident stock market bubble. These problems evolved into the financial crisis. Following very large declines in the stock market in September and October, 2008, we fielded our first survey which we called the Financial Crisis survey because at that time the news was dominated by the financial problems in the banking sector, the stock market bust, and the housing market. Unemployment had been increasing but it was still at a relatively modest $6.9 \%$. Although we were not in the field to capture the immediate effects of the largest part of the stock and housing declines, those prices did decline for a few more months following our first survey, so we were able to observe at least some immediate effects. Even as prices in the housing market stabilized and the stock market partially recovered, the unemployment rate continued to increase, reaching $10.1 \%$ in October 2009. The financial crisis became the Great Recession. With our monthly surveys we have observed the immediate effects of these large changes.

According to our measures almost $40 \%$ of households have been affected either by unemployment, negative home equity, arrears on their mortgage payments, or foreclosure. Additionally economic preparation for retirement, which is hard to measure, has undoubtedly been affected. Many people approaching retirement suffered substantial losses in their retirement accounts: indeed in the November 2008 survey, 25\% of respondents aged 50-59 reported they had lost more than $35 \%$ of their retirement savings, and some of them locked in their losses prior to the partial recovery in the stock market by selling out. Some persons retired unexpectedly early because of unemployment, leading to a reduction of economic resources in retirement which will be felt throughout their retirement years. Some younger workers who have suffered unemployment will not reach their expected level of lifetime earnings and will have reduced resources in retirement as well as during their working years.

Spending has been approximately constant since it reached its minimum in about November, 2009. Short-run expectations of stock market gains and housing prices gains have recovered somewhat, yet are still rather pessimistic; and, possibly more telling, longer-term expectations for those price increases have declined substantially and have shown no signs of recovery. The implication is that long-run expectations have become pessimistic relative to short-run expectations.

Expectations about unemployment have improved somewhat from their low point in May 2009 but they remain high: they predict that about 18\% of workers will experience unemployment over a 12 month period. Despite the public discussion of the necessity to work longer, expectations about working to age 62 among those not currently working declined by 10 percentage points. In our view this decline reflects long-term pessimism about the likelihood of a successful job search.

The recession officially ended in June 2009. A main component of that judgment is that the economy is no longer declining. According to our data the economic situation of the typical household is no longer worsening which is consistent with the end of the recession defined as negative change. However, when defined in terms of levels rather than rates of change, from the point of view of the typical household the Great Recession is not over. 


\section{References}

Agnew, Julie, Pierluigi Balduzzi, and Annika Sunden. (2003) "Portfolio Choice and Returns in a Large 401(k) Plan.” American Economic Review, 93, 193-205.

Ameriks, John, and Steven Zeldes. (2004) "How Do Household Portfolio Shares Vary with Age?” Working Paper, Columbia University.

Bentolila, S. and A. Ichino. 2008. "Unemployment and consumption near and far away from the Mediterranean.” Journal of Population Economics 21:255-280.

Curcuru, Stephanie, John Heaton, Deborah Lucas, and Damien Moore. (2009) "Heterogeneity and Portfolio Choice: Theory and Evidence.” In the Handbook of Financial Econometrics. Amsterdam: North Holland Publishing Company.

Curtin R, S. Presser, and E. Singer (2005), “Changes in Telephone Survey Nonresponse over the Past Quarter Century.” Public Opinion Quarterly 69: 87-98.

Gruber, J. 1997. "The Consumption Smoothing Benefits Of Unemployment Insurance." American Economic Review 87(1):192-206.

Gruber, J. 2000. "Cash Welfare As A Consumption Smoothing Mechanism For Divorced Mothers." Journal of Public Economics 75(2):157-182.

Hurd, M. D. 2009. "Subjective Probabilities in Household Surveys,” in Annual Review of Economics, Vol 1, 543-562

Hurd, M. D., M. Reti and S. Rohwedder. 2009. "The Effect of Large Capital Gains or Losses on Retirement.” In Developments in the Economics of Aging, ed. David Wise. Chicago: University of Chicago Press.

Mitchell, Olivia S., Gary R. Mottola, Stephan P. Utkus, and Takeshi Yamaguchi. (2006) “The Inattentive Participant: Portfolio Trading Behavior in 401(k) Plans.” Pension Research Council Working Paper No. 2006-5.

Stephens Jr., M. 2001. “The Long-run Consumption Effects of Earnings Shocks.” Review of Economics and Statistics 83(1):28-36.

Sullivan, J.X. 2008. "Borrowing During Unemployment: Unsecured Debt as a Safety Net.” Journal of Human Resources 43(2):383-412. 


\section{Appendix}

To track the effect of the financial crisis on American households, we began collecting data in the American Life Panel in November 2008, shortly after the sharp decline in the stock market in the preceding month. The second wave of the survey was administered to the same households in late February/early March 2009. The next wave was conducted in May 2009 which is when we have adopted a monthly survey schedule: during the first 10 days of every month respondents have been asked to complete one of our surveys. Basic monthly surveys are shorter than the first two waves that we conducted, eliciting just a subset of variables. Every three months we administer a long survey. Appendix Table 1 gives an overview table of the survey schedule and response rates.

Appendix Table 1: Survey schedule, survey length and response rates

\begin{tabular}{ccccccc}
\hline Wave & Survey & $\begin{array}{c}\text { Length of survey in } \\
\text { minutes } \\
\text { Mean* }\end{array}$ & Median & Responses & $\begin{array}{c}\text { Response rate } \\
{[\%]}\end{array}$ \\
\hline 1 & Nov08 & 19.3 & 16.6 & Initially unrestricted** & 2,056 & 76.4 \\
2 & Feb09 & 24.6 & 21.2 & $02 / 24-03 / 16 / 09=21$ days & 2,124 & 79.0 \\
3 & May09 & 15.0 & 11.2 & $05 / 01-05 / 10 / 09=10$ days & 2,086 & 77.5 \\
4 & Jun09 & 14.1 & 11.3 & $06 / 01-06 / 10 / 09=10$ days & 2,117 & 78.6 \\
5 & Jul09 & 26.2 & 21.8 & $07 / 01-07 / 10 / 09=10$ days & 2,139 & 79.4 \\
6 & Aug09 & 12.2 & 9.3 & $08 / 03-08 / 12 / 09=10$ days & 2,123 & 78.8 \\
7 & Sep09 & 12.3 & 9.3 & $09 / 01-09 / 10 / 09=10$ days & 2,157 & 80.1 \\
8 & Oct09 & 27.3 & 22.8 & $10 / 01-10 / 11 / 09=11$ days & 2,053 & 76.2 \\
9 & Nov09 & 13.9 & 10.8 & $11 / 02-11 / 11 / 09=10$ days & 2,082 & 77.3 \\
10 & Dec09 & 13.7 & 11.0 & $12 / 01-12 / 10 / 09=10$ days & 2,112 & 78.4 \\
11 & Jan10 & 27.5 & 23.3 & $01 / 01-01 / 10 / 10=10$ days & 2,129 & 79.1 \\
12 & Feb10 & 14.9 & 11.4 & $02 / 01-02 / 10 / 10=10$ days & 2,123 & 78.8 \\
13 & Mar10 & 13.8 & 10.4 & $03 / 01-03 / 10 / 10=10$ days & 2,084 & 77.4 \\
14 & Apr10 & 26.7 & 22.4 & $04 / 01-04 / 11 / 10=11$ days & 2,077 & 77.1 \\
\hline
\end{tabular}

${ }^{*}$ Calculation of average time to complete survey excludes cases with times of 300 min or more who appear to have interrupted their survey session.

** Over $90 \%$ of those who responded did so within the first 28 days. 


\section{Appendix Table 2: Items queried each month, grouped by actual screen display}

Screen 1:

\begin{tabular}{|l|}
\hline Mortgage \\
\hline Rent \\
\hline Electricity \\
\hline Water \\
\hline Heating fuel for the home \\
\hline Telephone, cable, Internet \\
\hline Car payments: interest and principal \\
\hline
\end{tabular}

Screen 2:

\begin{tabular}{|l|}
\hline Food and beverages \\
\hline Dining and/or drinking out \\
\hline Gasoline \\
\hline
\end{tabular}

Screen 3:

\begin{tabular}{|l|}
\hline Housekeeping supplies \\
\hline Housekeeping, dry cleaning, and laundry services \\
\hline Gardening and yard supplies \\
\hline Gardening and yard services \\
\hline
\end{tabular}

Screen 4:

\begin{tabular}{|l|}
\hline Clothing and apparel \\
\hline Personal care products and services \\
\hline Prescription and nonprescription medications \\
\hline Health care services \\
\hline Medical supplies \\
\hline
\end{tabular}

Screen 5:

Tickets to movies, sporting events, performing arts, etc.

Sports, including gym and exercise equipment such as bicycles, skis, and boats

Hobbies and leisure equipment

Screen 6:

Personal services, including cost of care for elderly and/or children, afterschool activities

Education, including tuition, room and board, books, and supplies

Other child-related spending, not yet reported, including toys, gear, and equipment 


\section{Appendix Table 3}

Additional 11 items queried quarterly beginning in the July survey about spending over previous three months

Screen 1:

Big ticket items

- Automobile or truck

- Refrigerator

- Stove and/or oven

- Washing machine and/or dryer

- Dishwasher

- Television

- Computer

Follow-up questions on big ticket items queried amounts, and in the case of cars how the purchase was financed.

Screen 2:

\begin{tabular}{|l|}
\hline Homeowner's or renter's insurance \\
\hline Property taxes \\
\hline Vehicle insurance \\
\hline Vehicle maintenance: parts, repairs, etc. \\
\hline Health insurance \\
\hline
\end{tabular}

Screen 3:

Trips and vacations

Home repair and maintenance materials

Home repair and maintenance services

Contributions to religious, educational, charitable, or political organizations

Cash or gifts to family and friends outside the household 


\section{Appendix Table 4: Effect of reconciliation screen on outliers}

\begin{tabular}{lrrrr}
\hline \multicolumn{5}{c}{ Maxima and standard deviations in spending before and after revision, May 2009 } \\
\hline & max before & max after & std dev before & std dev after \\
\cline { 2 - 5 } Food and beverages in & 100,000 & 7,000 & 3,809 & 254 \\
Food out & 150,120 & 2,500 & 3,766 & 135 \\
Gasoline & 8,000 & 2,000 & 586 & 119 \\
Clothing & 3,000 & 2,000 & 263 & 120 \\
Telecommunication & 17,900 & 1,800 & 942 & 72 \\
& & & & \\
All & 520,490 & 85,630 & 14,909 & 2,332 \\
\hline
\end{tabular}


Table 1

Percent of households with indicator of financial distress, panel

\begin{tabular}{lcc}
\hline & In month & Cumulative \\
\cline { 2 - 3 } Nov08 & 13.2 & 13.2 \\
Feb09 & 15.0 & 19.3 \\
May09 & 16.1 & 24.6 \\
Jun09 & 16.9 & 27.7 \\
Jul09 & 16.6 & 28.6 \\
Aug09 & 17.4 & 30.9 \\
Sep09 & 16.8 & 33.4 \\
Oct09 & 17.2 & 34.9 \\
Nov09 & 16.8 & 35.2 \\
Dec09 & 16.2 & 36.1 \\
Jan10 & 16.1 & 37.1 \\
Feb10 & 16.4 & 38.4 \\
Mar10 & 17.3 & 39.4 \\
Apr10 & 16.8 & 39.0 \\
Average monthly change (ppts) & 0.15 & \\
Total change Nov08-Apr10 (ppts) & 2.6 & \\
\hline Note: "Panel" consists of individuals who answered 10 or more of the 14 surveys. Financial \\
distress indicator is any of the following: unemployed, negative equity in house, behind more \\
than two months on mortgage, in foreclosure. Average monthly change based on regression of \\
percent of households on calendar time. Total change is compounded change over 17 months. \\
Average N = 1846 \\
\hline Note: Age < 50 had cumulative of 48\%; Age > 64 had cumulative of 16\%
\end{tabular}

Note: Age < 50 had cumulative of $48 \%$; Age $>64$ had cumulative of $16 \%$ 
Table 2

Self-reported housing values, thousands, cross-section

\begin{tabular}{lcc}
\hline & Mean & Median \\
\cline { 2 - 3 } Nov08 & 248,251 & 185,000 \\
Feb09 & 235,631 & 175,000 \\
Jun09 & 237,343 & 183,000 \\
Jul09 & 227,694 & 175,000 \\
Aug09 & 236,162 & 180,000 \\
Sep09 & 238,827 & 180,000 \\
Oct09 & 234,421 & 180,000 \\
Nov09 & 228,059 & 180,000 \\
Dec09 & 234,471 & 175,000 \\
Jan10 & 229,619 & 179,000 \\
Feb10 & 246,299 & 175,000 \\
Mar10 & 226,421 & 175,000 \\
Apr10 & 222,672 & 175,000 \\
Average monthly change (\%) & 222,011 & 167,000 \\
Total change Nov08-Apr10 (\%) & -0.42 & -0.33 \\
\hline Notes: Average monthly change based on regression of log house value on calendar time. \\
Total change is compounded monthly change over 17 months. Observations in cross- \\
section vary between 1509 and 1612. \\
\hline
\end{tabular}

Table 3

Percent of homeowners with mortgage who are currently more than two months behind on their mortgage payments, panel

\begin{tabular}{lc}
\hline May09 & 3.2 \\
Jun09 & 3.0 \\
Jul09 & 4.4 \\
Aug09 & 4.1 \\
Sep09 & 3.7 \\
Oct09 & 5.0 \\
Nov09 & 4.4 \\
Dec09 & 4.8 \\
Jan10 & 3.9 \\
Feb10 & 3.8 \\
Mar10 & 3.1 \\
Apr10 & 3.8 \\
Average monthly change (ppts) & 0.02 \\
Total change May-April (ppts) & 0.2 \\
\hline Notes: "Panel” consists of individuals who answered 10 or more of the 14 surveys. \\
Average monthly change based on regression of percent of homeowners on calendar time. \\
Total change is compounded monthly change over eleven months. Average N = 1018. \\
\hline
\end{tabular}




\begin{tabular}{|c|c|c|c|c|}
\hline \multicolumn{5}{|c|}{$\begin{array}{c}\text { Table } 4 \\
\text { Subjective probability of a housing price gain, } \\
\text { owners only, cross-section }\end{array}$} \\
\hline & \multicolumn{2}{|c|}{ one-year } & \multicolumn{2}{|c|}{ five-year } \\
\hline & Mean & Median & Mean & Median \\
\hline Feb09 & 31.5 & 25.0 & 56.4 & 55.0 \\
\hline May09 & 38.5 & 40.0 & & \\
\hline June09 & 38.8 & 40.0 & & \\
\hline July09 & 38.4 & 40.0 & 55.0 & 50.0 \\
\hline Oct09 & 39.5 & 45.0 & 55.7 & 55.0 \\
\hline Jan10 & 39.3 & 50.0 & 53.6 & 50.0 \\
\hline Apr10 & 36.3 & 30.0 & 51.3 & 50.0 \\
\hline Note: $\mathrm{Al}$ & $\mathrm{N}=15$ & & & \\
\hline
\end{tabular}

Table 5

Anticipations of spending change over next six months, percentage of respondents, cross-section

\begin{tabular}{lrrrrr}
\hline & $\mathrm{N}$ & Increase & Same & Decrease & All \\
\cline { 2 - 6 } Nov08 & 2053 & 8.3 & 71.3 & 20.4 & 100.0 \\
Feb09 & 2116 & 11.6 & 66.7 & 21.6 & 99.9 \\
Jul09 & 2115 & 13.4 & 70.8 & 15.8 & 100.0 \\
Oct09 & 2029 & 16.7 & 70.6 & 12.7 & 100.0 \\
Jan10 & 2085 & 16.9 & 71.0 & 12.0 & 99.9 \\
Apr10 & 2035 & 16.0 & 71.9 & 12.2 & 100.1 \\
\hline
\end{tabular}

Table 6

Anticipations of spending change over next six months and recollections of actual spending change over previous six months, percent of respondents, weighted, panel.

\begin{tabular}{lrrrr}
\hline & Higher & Same & Lower & All \\
\cline { 2 - 5 } Expectations, Feb/Mar 2009 & 9.4 & 67.0 & 23.5 & 99.9 \\
Recollections, July 2009 & 10.1 & 65.9 & 24.1 & 100.1 \\
\hline $\mathrm{N}=1093$
\end{tabular}


Table 7

Monthly spending on 25 categories, seasonally adjusted

\begin{tabular}{lcrrr}
\hline \multirow{2}{*}{ Month of survey } & \multicolumn{2}{c}{ cross-section } & \multicolumn{2}{c}{ panel } \\
\cline { 2 - 4 } May09 & Mean & Median & Mean & Median \\
Jun09 & 2,639 & 2,069 & 2,585 & 2,020 \\
Ju109 & 2,364 & 1,971 & 2,364 & 1,963 \\
Aug09 & 2,465 & 1,955 & 2,403 & 1,943 \\
Sep09 & 2,225 & 1,881 & 2,224 & 1,875 \\
Oct09 & 2,374 & 1,884 & 2,386 & 1,866 \\
Nov09 & 2,381 & 1,942 & 2,394 & 1,897 \\
Dec09 & 2,140 & 1,808 & 2,125 & 1,802 \\
Jan10 & 2,147 & 1,826 & 2,125 & 1,815 \\
Feb10 & 2,256 & 1,796 & 2,210 & 1,762 \\
Mar10 & 2,376 & 1,980 & 2,345 & 1,933 \\
Apr10 & 2,313 & 1,979 & 2,284 & 1,965 \\
Average monthly change (\%) & 2,214 & 1,881 & 2,189 & 1,868 \\
Total change (\%) & -1.0 & -0.5 & -1.0 & -0.5 \\
\hline Notes: "Panel” consists of individuals who answered 10 or more of the 14 surveys. Spending refers to the & -5.0 \\
month prior to the survey month. Average monthly change based on regression of log spending on calendar \\
time. Total change is compounded monthly change over 11 months. Observations in cross-section vary \\
between 2025 and 2130. Observations in panel average 1894. \\
\hline
\end{tabular}


Table 8

Monthly spending on food at home, food away from home (dining out), and total, panel

\begin{tabular}{lrrrrrr}
\hline & \multicolumn{3}{c}{ Mean } & \multicolumn{3}{c}{ Median } \\
\cline { 2 - 6 } Month of survey & Food in & Food out & Total & Food in & Food out & Total \\
\hline May09 & 352 & 140 & 492 & 300 & 100 & 440 \\
Jun09 & 332 & 130 & 462 & 300 & 100 & 400 \\
Ju109 & 330 & 123 & 453 & 300 & 100 & 400 \\
Aug09 & 316 & 119 & 435 & 300 & 80 & 375 \\
Sep09 & 312 & 117 & 429 & 300 & 80 & 390 \\
Oct09 & 322 & 119 & 441 & 300 & 80 & 400 \\
Nov09 & 314 & 114 & 427 & 300 & 70 & 375 \\
Dec09 & 313 & 109 & 422 & 300 & 65 & 375 \\
Jan10 & 337 & 121 & 458 & 300 & 75 & 400 \\
Feb10 & 316 & 105 & 421 & 300 & 60 & 375 \\
Mar10 & 317 & 108 & 424 & 300 & 70 & 379 \\
Apr10 & 320 & 116 & 436 & 300 & 80 & 385 \\
Average monthly change (\%) & -0.5 & -1.8 & -0.9 & 0.0 & -3.6 & -0.8 \\
Total change (\%) & -5.5 & -17.5 & -9.0 & 0.0 & -32.8 & -8.3 \\
\hline Notes: "Panel” consists of individuals who answered 10 or more of the 14 surveys. Spending refers to the month \\
prior to the survey month. Average monthly change based on regression of log spending on calendar time. Total \\
change is compounded monthly change over eleven months. Observations average 1894. \\
\hline
\end{tabular}


Table 9

Monthly spending on prescription drugs, health care services, and total, panel

\begin{tabular}{|c|c|c|c|c|c|c|}
\hline \multirow{3}{*}{ Month of survey } & \multicolumn{3}{|c|}{ Mean } & \multicolumn{3}{|c|}{ Median } \\
\hline & \multicolumn{3}{|c|}{ Health care } & \multicolumn{3}{|c|}{ Health care } \\
\hline & Drugs & services & Total & Drugs & services & Total \\
\hline May09 & 60 & 109 & 169 & 30 & 15 & 70 \\
\hline Jun09 & 62 & 88 & 150 & 26 & 0 & 57 \\
\hline Jul09 & 50 & 92 & 142 & 20 & 0 & 50 \\
\hline Aug09 & 51 & 88 & 139 & 20 & 0 & 45 \\
\hline Sep09 & 48 & 65 & 113 & 20 & 0 & 40 \\
\hline Oct09 & 50 & 72 & 123 & 22 & 0 & 45 \\
\hline Nov09 & 52 & 67 & 118 & 20 & 0 & 40 \\
\hline Dec09 & 50 & 60 & 110 & 20 & 0 & 35 \\
\hline Jan10 & 54 & 91 & 144 & 25 & 0 & 46 \\
\hline Feb10 & 50 & 71 & 122 & 20 & 0 & 35 \\
\hline Mar10 & 48 & 64 & 111 & 20 & 0 & 35 \\
\hline Apr10 & 50 & 91 & 141 & 20 & 0 & 45 \\
\hline Average monthly change (\%) & -1.4 & -2.4 & -2.0 & -2.0 & & -4.2 \\
\hline Total change (\%) & -13.8 & -23.0 & -19.7 & -20.0 & & -37.3 \\
\hline
\end{tabular}




\section{Table 10}

Credit card holdings, payments and debt, cross-section

\begin{tabular}{|c|c|c|c|c|}
\hline & $\begin{array}{r}\text { Percent } \\
\text { with credit } \\
\text { card }\end{array}$ & $\begin{array}{l}\text { Percent of credit } \\
\text { card holders who } \\
\text { pay off balance }\end{array}$ & $\begin{array}{r}\text { Debt carried } \\
\text { over, } \\
\text { conditional, } \\
\text { mean }\end{array}$ & $\begin{array}{r}\text { Debt carried over, } \\
\text { conditional, } \\
\text { median }\end{array}$ \\
\hline Nov08 & 78.2 & 41.8 & 8,540 & 4,000 \\
\hline Feb09 & 75.6 & 43.3 & 8,383 & 4,000 \\
\hline May09 & 77.3 & 43.2 & 9,339 & 5,000 \\
\hline Jun09 & 76.4 & 41.1 & 8,973 & 5,000 \\
\hline Jul09 & 75.6 & 42.2 & 9,985 & 5,000 \\
\hline Aug09 & 75.1 & 41.6 & 9,606 & 5,000 \\
\hline Sep09 & 76.1 & 42.8 & 9,608 & 5,000 \\
\hline Oct09 & 73.5 & 41.8 & 9,805 & 5,000 \\
\hline Nov09 & 75.8 & 43.4 & 10,348 & 5,000 \\
\hline Dec09 & 75.4 & 44.3 & 10,280 & 5,300 \\
\hline Jan10 & 74.8 & 42.7 & 10,122 & 5,000 \\
\hline Feb10 & 75.4 & 45.5 & 10,674 & 5,600 \\
\hline Mar10 & 74.6 & 45.2 & 10,398 & 5,000 \\
\hline Apr10 & 74.6 & 46.6 & 9,859 & 5,000 \\
\hline Average monthly change & -0.2 & 0.2 & 1.3 & 1.4 \\
\hline Total change & -2.8 & 3.8 & 24.6 & 27.5 \\
\hline
\end{tabular}




\begin{tabular}{lrrrr}
\hline \multirow{4}{*}{ Subjective probability of a stock market gain, cross-section } \\
\hline & \multicolumn{3}{c}{ One-year } & \multicolumn{2}{c}{10 -year } \\
\cline { 2 - 5 } Mean & Median & Mean & Median \\
\cline { 2 - 5 } Nov08 & 40.3 & 50.0 & 60.8 & 65.0 \\
Feb09 & 36.6 & 36.0 & 58.0 & 60.0 \\
May09 & 41.0 & 50.0 & 59.4 & 60.0 \\
Jun09 & 41.0 & 50.0 & 56.9 & 50.0 \\
Jul09 & 39.2 & 45.0 & 52.8 & 50.0 \\
Aug09 & 39.9 & 45.0 & 55.2 & 50.0 \\
Sep09 & 40.3 & 50.0 & 53.6 & 50.0 \\
Oct09 & 41.5 & 50.0 & 52.3 & 50.0 \\
Nov09 & 43.1 & 50.0 & 55.3 & 50.0 \\
Dec09 & 41.4 & 50.0 & 53.2 & 50.0 \\
Jan10 & 41.7 & 50.0 & 50.8 & 50.0 \\
Feb10 & 40.7 & 50.0 & 52.3 & 50.0 \\
Mar10 & 40.8 & 50.0 & 52.0 & 50.0 \\
Apr10 & 40.3 & 50.0 & 50.4 & 50.0 \\
\hline
\end{tabular}

Observations range between 1996 and 2118. 
Table 12

Percent of respondents expressing dissatisfaction, panel

\begin{tabular}{lccc}
\hline & $\begin{array}{r}\text { Life satisfaction, } \\
\text { dissatisfied or very } \\
\text { dissatisfied }\end{array}$ & $\begin{array}{r}\text { Household income } \\
\text { satisfaction, dissatisfied } \\
\text { or very dissatisfied }\end{array}$ & $\begin{array}{r}\text { Economic situation, } \\
\text { dissatisfied or very } \\
\text { dissatisfied }\end{array}$ \\
\cline { 2 - 4 } Nov08 & -- & 33.8 & 44.9 \\
Feb09 & -- & 33.9 & 42.4 \\
Jun09 & 7.1 & 30.2 & 35.0 \\
Ju109 & 7.3 & 30.7 & 34.3 \\
Aug09 & 7.9 & 33.7 & 36.3 \\
Sep09 & 9.6 & 32.9 & 38.6 \\
Oct09 & 9.1 & 33.4 & 34.7 \\
Nov09 & 9.5 & 33.4 & 35.9 \\
Dec09 & 9.7 & 35.4 & 36.8 \\
Jan10 & 10.7 & 33.2 & 35.6 \\
Feb10 & 10.2 & 33.2 & 35.3 \\
Mar10 & 11.3 & 33.2 & 35.7 \\
Apr10 & 11.5 & 31.3 & 35.9 \\
\hline Note: "Panel” consists of individuals who answered 10 or more of the 14 surveys. Average & Ans \\
observations are 1817. Life satisfaction measure in Nov08 and Feb09 not comparable with \\
later waves because of difference in scales.
\end{tabular}


Table 13

Percent of respondents expressing low levels of health and of affect, panel

\begin{tabular}{lccccc}
\hline & $\begin{array}{c}\text { Self-rated } \\
\text { health, fair } \\
\text { or poor }\end{array}$ & $\begin{array}{c}\text { Feeling worn } \\
\text { out all to a } \\
\text { good bit of } \\
\text { the time }\end{array}$ & $\begin{array}{c}\text { Feeling } \\
\text { happy some } \\
\text { to none of } \\
\text { the time }\end{array}$ & $\begin{array}{c}\text { Difficulty } \\
\text { sleeping, } \\
\text { moderate to } \\
\text { extreme }\end{array}$ & $\begin{array}{c}\text { Depression } \\
\text { problems, } \\
\text { moderate to } \\
\text { extreme }\end{array}$ \\
\hline Nov08 & 16.0 & 27.9 & 25.2 & 33.8 & 17.0 \\
Feb09 & 16.3 & 26.1 & 26.6 & 29.3 & 18.4 \\
May09 & 13.8 & 29.0 & 24.0 & 31.7 & 16.5 \\
Jun09 & 13.4 & 23.9 & 21.1 & 29.8 & 16.3 \\
Jul09 & 14.2 & 27.4 & 21.9 & 24.9 & 16.1 \\
Aug09 & 13.5 & 28.8 & 22.4 & 26.2 & 17.6 \\
Sep09 & 12.7 & 28.1 & 21.8 & 27.3 & 15.5 \\
Oct09 & 12.9 & 25.8 & 23.2 & 25.6 & 17.5 \\
Nov09 & 15.0 & 27.4 & 24.0 & 25.4 & 17.2 \\
Dec09 & 14.2 & 28.8 & 23.9 & 25.3 & 16.3 \\
Jan10 & 15.5 & 26.6 & 23.1 & 25.4 & 16.8 \\
Feb10 & 14.4 & 26.9 & 25.4 & 24.5 & 18.0 \\
Mar10 & 13.5 & 27.5 & 26.4 & 23.5 & 17.0 \\
Apr10 & 13.5 & 28.9 & 25.2 & 24.7 & 16.6 \\
\hline Note: “Panel” consists of individuals who answered 10 or more of the 14 surveys. Average N varies between \\
1701 and 1888 depending on item.
\end{tabular}




\section{Table 14}

Average subjective probability of working past age 62 (P62), ages 45-61, cross-section

\begin{tabular}{|c|c|c|c|c|c|c|c|c|c|c|}
\hline \multirow[b]{4}{*}{ Wave } & \multicolumn{4}{|c|}{ Age $45-52$} & \multicolumn{4}{|c|}{ Age $53-61$} & \multirow{2}{*}{\multicolumn{2}{|c|}{ All }} \\
\hline & \multirow{3}{*}{$\begin{array}{c}\text { Fraction } \\
\text { working } \\
\text { for pay }\end{array}$} & \multirow{2}{*}{\multicolumn{3}{|c|}{$\begin{array}{c}\text { P62 } \\
\text { Working for Pay }\end{array}$}} & \multirow{3}{*}{$\begin{array}{c}\text { Fraction } \\
\text { working } \\
\text { for pay }\end{array}$} & \multicolumn{3}{|c|}{ P62 } & & \\
\hline & & & & & & \multicolumn{3}{|c|}{ Working for Pay } & \multirow[b]{2}{*}{$\mathrm{N}$} & \multirow[b]{2}{*}{ P62 } \\
\hline & & Yes & No & All & & Yes & No & All & & \\
\hline Nov08 & & 71.3 & -- & -- & & 71.8 & -- & -- & -- & - \\
\hline Feb09 & 0.742 & 67.9 & 39.6 & 60.6 & 0.588 & 71.9 & 26.7 & 53.3 & 988 & 57.5 \\
\hline Jul09 & 0.733 & 68.1 & 42.0 & 61.1 & 0.567 & 70.2 & 29.0 & 52.4 & 980 & 57.5 \\
\hline Oct09 & 0.792 & 66.9 & 37.3 & 60.7 & 0.601 & 69.8 & 29.8 & 53.8 & 932 & 58.0 \\
\hline Jan10 & 0.758 & 69.1 & 34.6 & 60.8 & 0.559 & 68.7 & 33.2 & 53.0 & 948 & 57.6 \\
\hline Apr10 & 0.762 & 65.2 & 29.2 & 56.7 & 0.570 & 67.5 & 28.9 & 50.9 & 932 & 54.3 \\
\hline All & 0.757 & 68.1 & 36.7 & 60.0 & 0.577 & 70.1 & 29.5 & 52.7 & 4,780 & 57.0 \\
\hline
\end{tabular}

Note: N does not include Nov08 observations because in that wave P62 was only asked of workers. 
Table 15

Actions taken in response to unemployment, percent of households

\begin{tabular}{lr}
\hline Reduced spending & 85.2 \\
Reduced saving & 46.4 \\
Behind on mortgage & 8.6 \\
Behind on rent & 16.9 \\
Behind on other bills & 36.1 \\
Other & 2.4 \\
\hline
\end{tabular}

$\mathrm{N}=699$

Table 16

Replacement for income loss, \% of households

Unemployment benefits 39.2

Took money out of savings

35.6

Financial help from family or friends

27.0

Borrowed money or increased credit card debt

18.0

Respondent took temporary job

13.3

Spouse/partner took temporary job $\quad 9.4$

None of the above. Found a job soon 8.5

\begin{tabular}{ll} 
Respondent began working or increased working hours $\quad 7.9$ \\
\hline
\end{tabular}

Spouse/partner began working or increased working hours $\quad 4.5$

$\mathrm{N}=699$ 
Table 17

Subjective probability of losing job over next twelve months, workers, cross-section

\begin{tabular}{lrr}
\hline & $\mathrm{N}$ & Probability \\
Nov08 & 1188 & 20.2 \\
Feb09 & 1192 & 20.3 \\
May09 & 1154 & 21.9 \\
Jun09 & 1162 & 19.1 \\
Jul09 & 1147 & 17.9 \\
Aug09 & 1143 & 19.1 \\
Sep09 & 1181 & 18.5 \\
Oct09 & 1119 & 19.6 \\
Nov09 & 1128 & 19.5 \\
Dec09 & 1153 & 19.2 \\
Jan10 & 1147 & 18.4 \\
Feb10 & 1159 & 18.8 \\
Mar10 & 1154 & 18.9 \\
Apr10 & 1145 & 17.8 \\
Average monthly change (percentage points) & & -0.1 \\
Total change (percentage points) & -2.2 \\
\hline Note: Average monthly change based on regression of percent probability on calendar time. Total change \\
is compounded monthly change over 17 months.
\end{tabular}

Table 18

Average subjective probability of unemployment over next 12 months and actual frequency (\%) among workers in initial wave, panel

\begin{tabular}{lrrr}
\hline Initial wave & $\mathrm{N}$ & Average probability & Actual frequency \\
\hline Nov08 & 1188 & 20.2 & 19.4 \\
May09 & 1153 & 21.9 & 16.9 \\
Jun09 & 1161 & 19.1 & 13.5 \\
Total & 3502 & 20.4 & 16.6 \\
\hline
\end{tabular}


Table 19

Distribution (\%) of homeownership, mortgage ownership, and mortgage delinquency by unemployment status

\begin{tabular}{crrrrr}
\hline \multirow{2}{*}{ Unemployed } & Not home & no mortgage & mortgage, not \\
owner & 32.2 & 19.7 & $\begin{array}{r}\text { mortgage, } \\
\text { delinquent }\end{array}$ & All \\
& 53.6 & 11.5 & 46.6 & 1.5 & 100.0 \\
no & 34.5 & 18.8 & 31.4 & 3.5 & 100.0 \\
yes & Total & 45.0 & 1.7 & 100.0 \\
\hline
\end{tabular}

Note: $\mathrm{N}=29,278$. "Unemployed" is unemployed of either respondent or spouse.

Unemployment rate is $10.8 \%$. Delinquency defined as more than two months behind on mortgage payment. 
Table 20

Spending before (wave t) and after (wave $t+1$ ) a household employment transition

\begin{tabular}{lrrrrrrrr}
\hline & & \multicolumn{9}{c}{ mean spending } & \multicolumn{3}{c}{ median spending } & \\
\cline { 3 - 8 } $\begin{array}{l}\text { Employment } \\
\text { transition }\end{array}$ & $\mathrm{N}$ & Wave $\mathrm{t}$ & $\begin{array}{r}\text { Wave } \\
\mathrm{t}+1\end{array}$ & $\begin{array}{r}\% \\
\text { change }\end{array}$ & Wave $\mathrm{r}$ & $\begin{array}{r}\text { Wave } \\
\mathrm{t}+1\end{array}$ & $\begin{array}{r}\% \\
\text { change }\end{array}$ & $\begin{array}{r}\text { Median of } \\
\text { individual } \\
\text { changes (\%) }\end{array}$ \\
\hline E to E & 14,053 & 2551 & 2505 & -1.8 & 2135 & 2120 & -0.7 & -0.3 \\
E to U & 350 & 2208 & 2125 & -3.7 & 1884 & 1930 & 2.4 & -2.8 \\
U to E & 378 & 2303 & 2248 & -2.4 & 1931 & 1853 & -4.1 & -2.7 \\
U to U & 1,587 & 1883 & 1850 & -1.7 & 1535 & 1490 & -2.9 & -3.0 \\
All & 16,368 & 2460 & 2415 & -1.8 & 2062 & 2042 & -1.0 & -0.6 \\
\hline
\end{tabular}

Note: Employment transitions of respondent or spouse. E refers to employed and U refers to unemployed.

\begin{tabular}{|c|c|c|c|c|c|c|c|}
\hline \multicolumn{8}{|c|}{$\begin{array}{c}\text { Table } 21 \\
\text { Spending prior to and following a job loss }\end{array}$} \\
\hline & \multirow[b]{2}{*}{$\mathrm{N}$} & \multicolumn{3}{|c|}{ Mean } & \multicolumn{3}{|c|}{ Median } \\
\hline & & Wave $\mathrm{t}-3$ & Wave $\mathrm{t}$ & $\begin{array}{l}\text { percent } \\
\text { change }\end{array}$ & Wave $\mathrm{t}$ & Wave $t+3$ & $\begin{array}{l}\text { percent } \\
\text { change }\end{array}$ \\
\hline No job loss & 3,035 & 2,777 & 2,731 & -1.7 & 2,270 & 2,243 & -1.2 \\
\hline Job loss, no income loss & 40 & 2,145 & 1,983 & -7.6 & 1,859 & 1,840 & -1.0 \\
\hline Job loss, income loss & 323 & 2,286 & 2,019 & -11.7 & 1,925 & 1,719 & -10.7 \\
\hline All & 3,398 & 2,711 & 2,638 & -2.7 & 2,218 & 2,173 & -2.0 \\
\hline
\end{tabular}

Table 22

Employment transitions and percent of persons with health insurance

\begin{tabular}{lrrrrrrrrr}
\hline & \multicolumn{3}{c}{ Singles } & \multicolumn{3}{c}{ Couples } & \multicolumn{3}{c}{ All } \\
\cline { 2 - 9 } $\begin{array}{l}\text { Employment } \\
\text { transition }\end{array}$ & $\mathrm{N}$ & wave t & wave $\mathrm{t}+1$ & $\mathrm{~N}$ & wave t & wave $\mathrm{t}+1$ & $\mathrm{~N}$ & wave t & wave $\mathrm{t}+1$ \\
& & & & & & & & & \\
\hline E to E & 3231 & 82.8 & 82.9 & 7705 & 88.5 & 88.6 & 10936 & 86.5 & 86.6 \\
E to U & 85 & 55.0 & 32.4 & 94 & 72.7 & 69.4 & 179 & 62.3 & 47.7 \\
U to E & 88 & 47.2 & 46.6 & 121 & 66.6 & 69.3 & 209 & 56.5 & 57.5 \\
U to U & 532 & 28.3 & 29.8 & 487 & 60.6 & 60.4 & 1019 & 41.2 & 42.0 \\
All & 3936 & 72.7 & 72.3 & 8407 & 86.1 & 86.3 & 12343 & 80.9 & 80.8 \\
\hline
\end{tabular}

Note: Employment transitions of respondent: E refers to employed and U refers to unemployed. 
Figure 1. Housing price indices for four cities and 20-city average

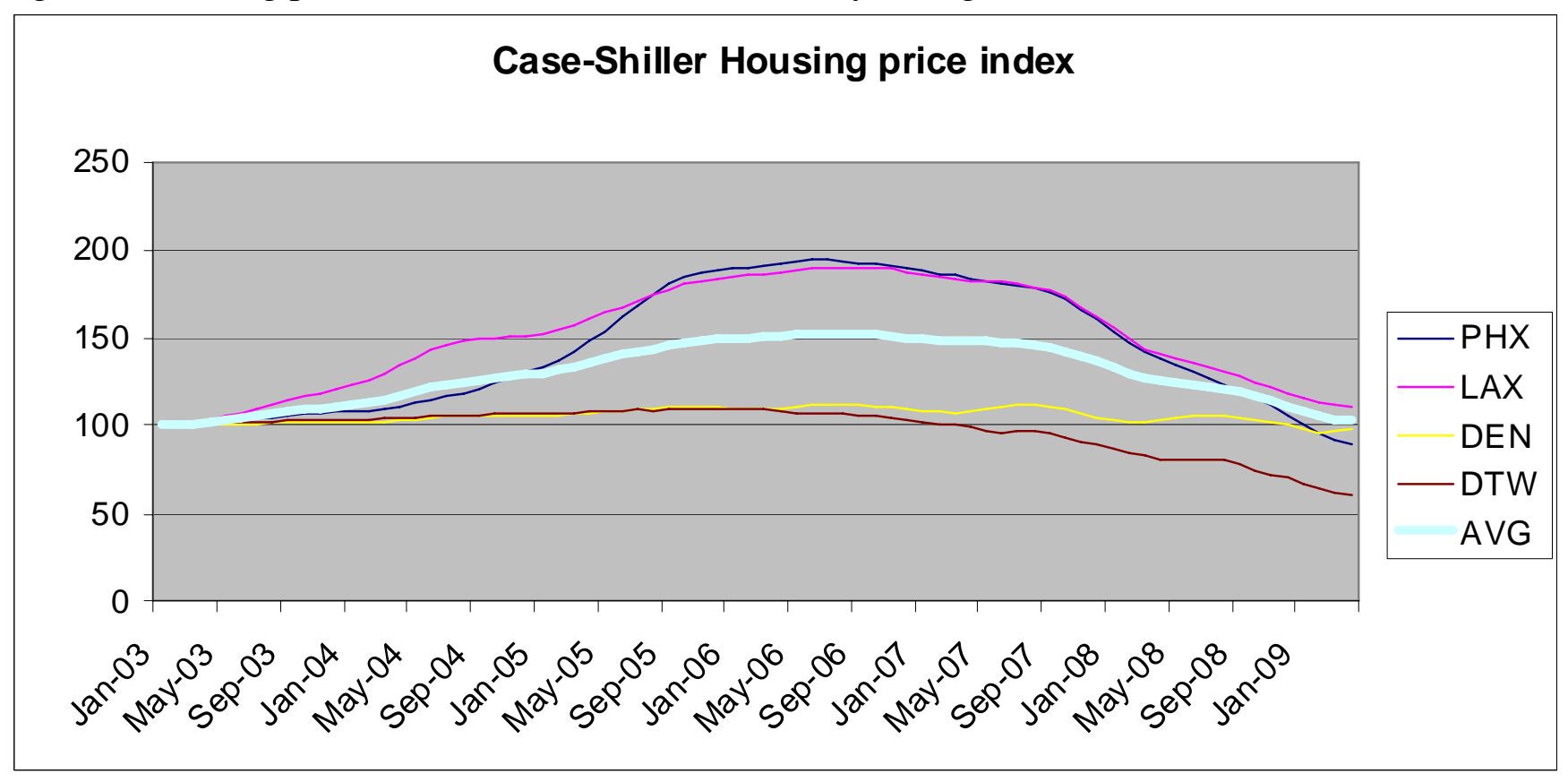


Figure 2. Employment transitions, and health and affect

Life Satisfaction: \% dissatisfied or very dissatisfied

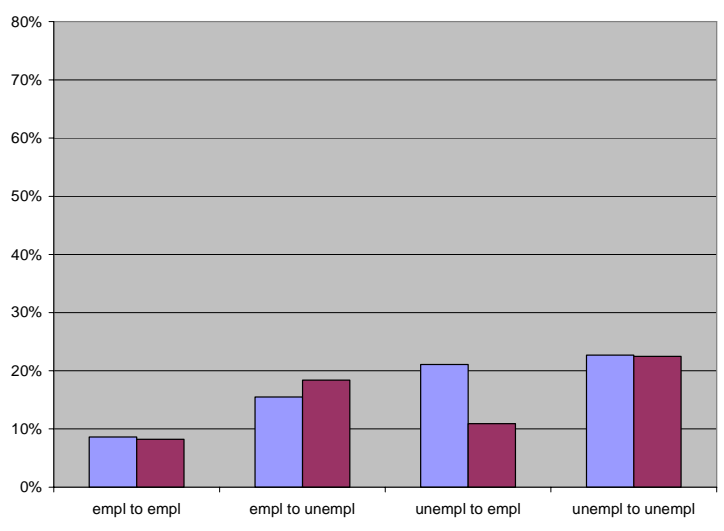

Satisfaction with Economic Situation: \% dissatisfied or very dissatisfied

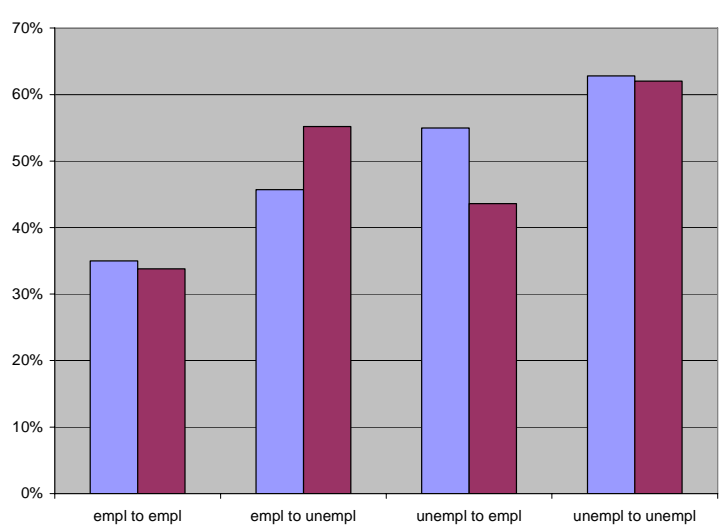

Difficulty Sleeping: \% with moderate to extreme difficulty sleeping

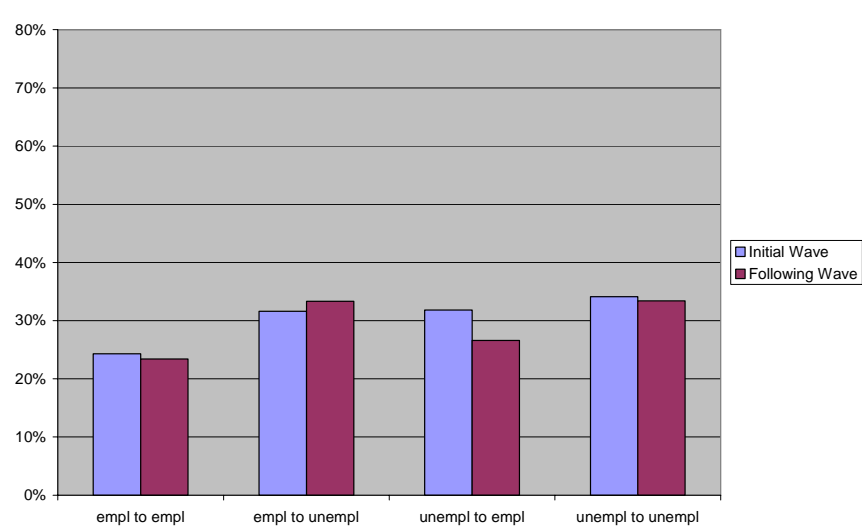

HH Income Satisfaction: \% dissatisfied or very dissatisfied

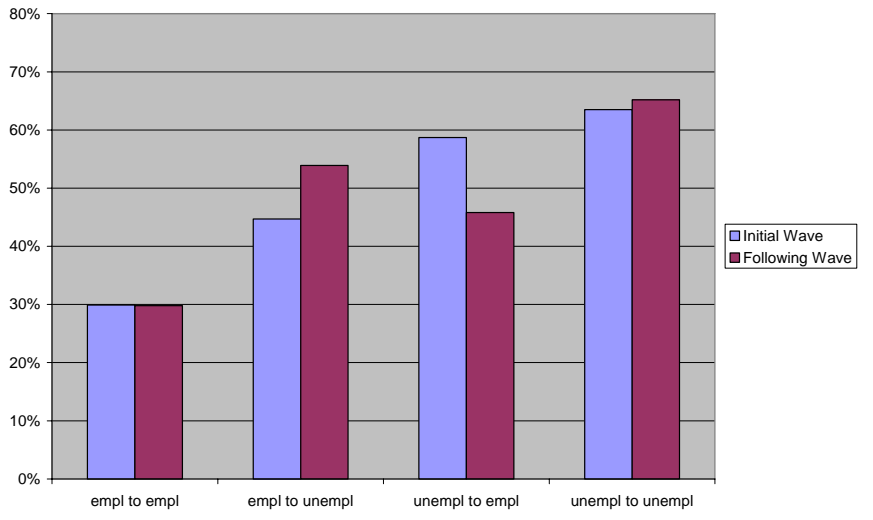

Self-Rated Health: \% with fair or poor self-reported health

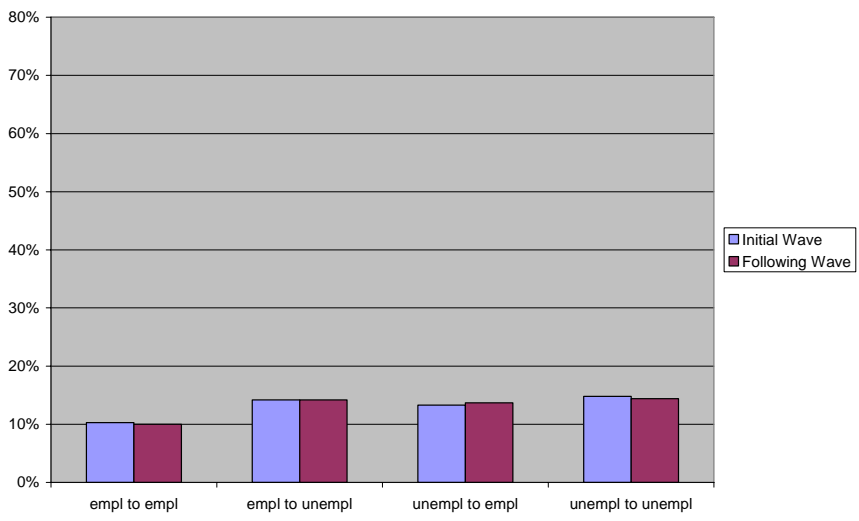

Feeling Depressed: \% with moderate to extreme depressions problems

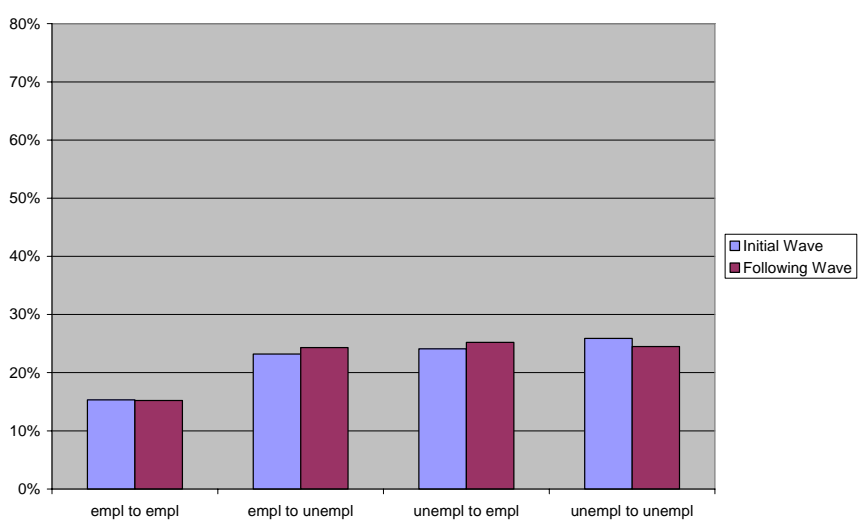


Figure 2 continued

Worn out: \% feeling worn out all to a good bit of the time

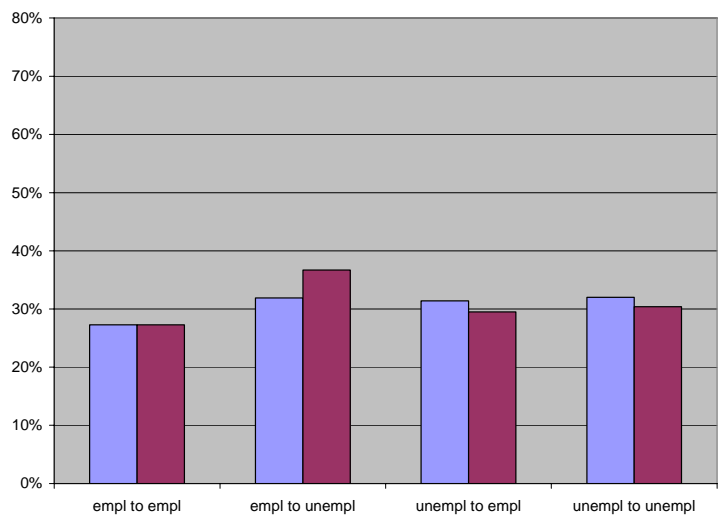

Note: all figures are weighted averages
Feeling happy: \% feeling happy little to none of the time

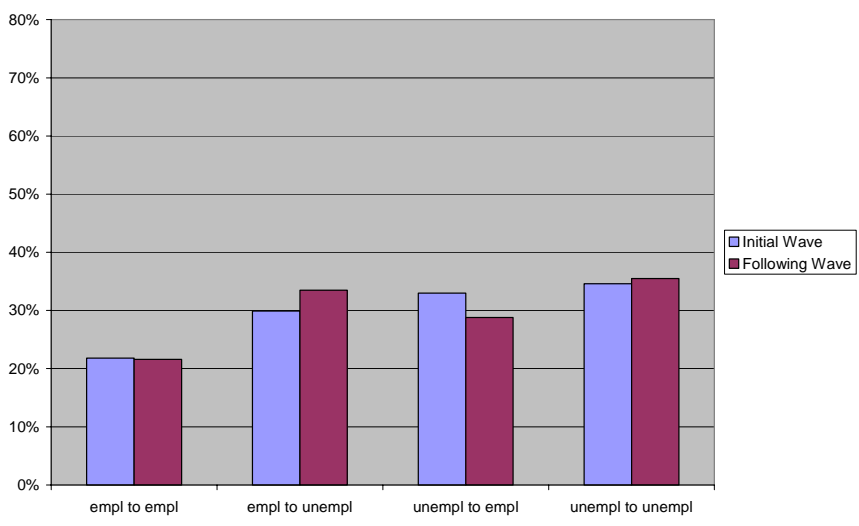

